Prepared for the U.S. Department of Energy

under Contract DE-AC05-76RL01830

\title{
Review of Recent Literature
}

Relevant to the Environmental

Effects of Marine and Hydrokinetic

Energy Devices

Task 2.1.3: Effects on Aquatic Organisms Fiscal Year 2012 Progress Report

Environmental Effects of Marine and Hydrokinetic Energy

RK Kropp

January 2013

Pacific Northwest

NATIONAL LABORATORY

Proudly Operated by Battelle Since 1965 



\title{
DISCI AIMER
}

This report was prepared as an account of work sponsored by an agency of the United States Government. Neither the United States Government nor any agency thereof, nor Battelle Memorial Institute, nor any of their employees, makes any warranty, express or implied, or assumes any legal liability or responsibility for the accuracy, completeness, or usefulness of any information, apparatus, product, or process disclosed, or represents that its use would not infringe privately owned rights. Reference herein to any specific commercial product, process, or service by trade name, trademark, manufacturer, or otherwise does not necessarily constitute or imply its endorsement, recommendation, or favoring by the United States Government or any agency thereof, or Battelle Memorial Institute. The views and opinions of authors expressed herein do not necessarily state or reflect those of the United States Government or any agency thereof.

\author{
PACIFIC NORIHWEST NATIONAL LABORATORY \\ operated by \\ BATTELLE \\ for the \\ UNITED STATES DEPARTMENT OF ENERGY \\ under Contract DE-AC05-76RL01830
}

Printed in the United States of America
$\Lambda$ vailable to DOE and DOE contractors from the Office of Scientific and Technical Information,
P.O. Box 62, Oak Ridge, TN 37831-0062;
ph: (865) 576-8401
fax: (865) 576-5728
email: reports $(\hat{a})$ adonis.osti.gov

\footnotetext{
Available to the public from the National Technical Information Service, U.S. Department of Commerce, 5285 Port Royal Rd., Springfield, VA 22161 ph: (800) 553-6847 fax: $(703) 605-6900$ email: orders $(\underline{a}$ ntis.fedworld.gov online ordering: http://www.ntis.gov/ordering.htm
}

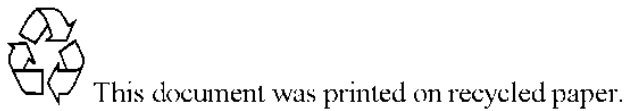




\section{Review of Recent Literature Relevant to the Environmental Effects of Marine and Hydrokinetic Energy Devices}

Task 2.1.3: Effects on Aquatic Organisms Fiscal Year 2012 Progress Report

Environmental Effects of Marine and Hydrokinetic Energy

RK Kropp

January 2013

Prepared for the U.S. Department of Energy

under Contract DE-AC05-76RL01830

Pacific Northwest National Laboratory

Richland, Washington 99352 


\begin{abstract}
A literature search was conducted to identify recent articles that would be useful to help assess the potential environmental effects of renewable energy development in the ocean, with emphasis on seabirds and fish. It was clear that the potential effects frequently were offered as hypotheses that were not supported by appropriate documentation. Therefore, the literature search was refined and focused on trying to obtain the necessary information to support or challenge a proposed potential effect.

Two case studies were developed to investigate the validity of the concerns that an offshore wave park proposed for development off Reedsport, Oregon, would affect two federally protected species, the marbled murrelet (Brachyramphus marmoratus) and the green sturgeon (Acipenser medirostris). The literature review showed that the marbled murrelets could encounter the wave park proposed for Reedsport, but most birds would pass the park over shallower waters that are closer to shore. Although the interaction between the proposed wave park and marbled murrelets cannot be excluded, the description of the wave park and the literature on murrelet biology suggest that the likelihood of an adverse interaction between the park and murrelets is low. Similarly, some Southern green sturgeons, a distinct population segment, migrating north to estuaries along the Oregon and Washington coasts would encounter the wave park proposed for Reedsport and its associated shoreward transmission cable, but most sturgeons would pass the park in shallower waters that are closer to shore. Migrating sturgeons would be exposed to some electromagnetic field levels, but those would not be expected to adversely affect the sturgeon population because field strength diminishes to levels near background at short distances from the cable and most fish swim relatively close to shore where they would only encounter the single transmission cable.
\end{abstract}





\section{Project Overview}

Energy generated from the world's oceans and rivers offers the potential to make substantial contributions to the domestic and global renewable energy supply. The U.S. Department of Energy (DOE) Office of Energy Efficiency and Renewable Energy (EERE) Wind and Water Power Program supports the emerging marine and hydrokinetic (MHK) energy industry. As major players in an emerging industry, MHK project developers face challenges with siting, permitting, construction, and operation of pilot- and commercial-scale facilities, as well as the need to develop robust technologies, secure financing, and gain public acceptance.

In many cases, little is known about the potential effects of MHK energy generation on the aquatic environment from a small number of devices or a large-scale commercial array. Nor do we understand potential effects that may occur after years or decades of operation. This lack of knowledge affects the solvency of the industry, the actions of regulatory agencies, the opinions and concerns of stakeholder groups, and the commitment of energy project developers and investors.

To unravel and address the complexity of environmental issues associated with MHK energy, Pacific Northwest National Laboratory (PNNL) is developing a program of research and development that draws on the knowledge of the industry, regulators, and stakeholders and builds on investments made by the EERE Wind and Water Power Program. The PNNL program of research and development - together with complementary efforts of other national laboratories, national marine renewable energy centers, universities, and industry—supports DOE's market acceleration activities through focused research and development on environmental effects and siting issues.

Research areas addressed include

- Categorizing and evaluating effects of stressors - Information on the environmental risks from MHK devices, including data obtained from in situ testing and laboratory experiments (see other tasks below) will be compiled in a knowledge management system known as Tethys to facilitate the creation, annotation, and exchange of information on environmental effects of MHK technologies. Tethys will support the Environmental Risk Evaluation System (ERES) that can be used by developers, regulators, and other stakeholders to assess relative risks associated with MHK technologies, site characteristics, waterbody characteristics, and receptors (i.e., habitat, marine mammals, and fish). Development of Tethys and the ERES will require focused input from various stakeholders to ensure accuracy and alignment with other needs.

- Effects on physical systems - Computational numerical modeling will be used to understand the effects of energy removal on water bodies from the short- and long-term operation of MHK devices and arrays. Initially, PNNL's three-dimensional coastal circulation and transport model of Puget Sound will be adapted to test and optimize simulated tidal technologies that resemble those currently in proposal, laboratory trial, or pilot study test stages. This task includes assessing changes to the physical environment (currents, waves, sediments, and water quality) and the potential effects of these changes on the aquatic food webs) resulting from operation of MHK devices at both pilot- and commercial-scale in river and ocean settings.

- Effects on aquatic organisms - Testing protocols and laboratory exposure experiments will be developed and implemented to evaluate the potential for adverse effects from operation of MHK devices in the aquatic environment. Initial studies will focus on electromagnetic field effects, noise 
associated with construction and operation of MHK devices, and assessment of the potential risk of physical interaction of aquatic organisms with devices. A variety of fish species and invertebrates will be used as test animals, chosen due to their proximity to and potential susceptibility to MHK devices.

- Permitting and planning - Structured stakeholder communication and outreach activities will provide critical information to the project team to support execution of other project tasks. Input from MHK technology and project developers, regulators and natural resource management agencies, environmental groups, and other stakeholder groups will be used to develop the user interface of Tethys, populate the database, define the risk attributes of the ERES, and communicate results of numerical modeling and laboratory studies of exposure of test animals to MHK stressors. This task will also include activities to promote consideration of renewable ocean energy in national and local Coastal and Marine Spatial Planning activities.

The team for the Environmental Effects of Marine and Hydrokinetic Energy Development project is made up of staff, faculty, and students from

- Pacific Northwest National Laboratory

- Marine Sciences Laboratory (Sequim and Seattle, Washington)

- Risk and Decision Sciences (Richland, Washington)

- Knowledge Systems (Richland, Washington)

- Oak Ridge National Laboratory (Oak Ridge, Tennessee)

- Sandia National Laboratories (Albuquerque, New Mexico; Carlsbad, California)

- Oregon State University, Northwest National Marine Renewable Energy Center (Newport, Oregon)

- University of Washington, Northwest National Marine Renewable Energy Center (Seattle, Washington)

- Pacific Energy Ventures (Portland, Oregon). 


\section{Acronyms and Abbreviations}

\begin{tabular}{|c|c|}
\hline ac & acre(s) \\
\hline B-field & magnetic field \\
\hline $\mathrm{cm}$ & centimeter(s) \\
\hline d & $\operatorname{day}(s)$ \\
\hline DOE & U.S. Department of Energy \\
\hline DPS & distinct population segment(s) \\
\hline E-field & electric field \\
\hline EERE & DOE Office of Energy Efficiency and Renewable Energy \\
\hline EMF & electromagnetic field \\
\hline ERES & Environmental Risk Evaluation System \\
\hline ESA & Endangered Species Act of 1973 \\
\hline FAD & fish-attraction device \\
\hline FERC & Federal Energy Regulatory Commission \\
\hline FST & fixation index \\
\hline FY & fiscal year \\
\hline $\mathrm{ft}$ & foot (feet) \\
\hline ha & hectare(s) \\
\hline $\mathrm{Hz}$ & hertz \\
\hline iE-field & indirect electric field \\
\hline in. & inch(es) \\
\hline $\mathrm{kg}$ & kilogram(s) \\
\hline $\mathrm{km}$ & kilometer(s) \\
\hline $\mathrm{m}$ & meter(s) \\
\hline $\mathrm{mm}$ & millimeter(s) \\
\hline MHK & marine and hydrokinetic \\
\hline mph & miles per hour \\
\hline NMFS & National Marine Fisheries Service \\
\hline NOAA & National Oceanic and Atmospheric Administration \\
\hline nmi & nautical mile(s) \\
\hline OPT & Reedsport OPT Wave Park, LLC \\
\hline $\mathrm{OZ}$ & ounce(s) \\
\hline PNNL & Pacific Northwest National Laboratory \\
\hline RIT & Recovery Implementation Team \\
\hline RPM & reasonable and prudent measure \\
\hline S & second(s) \\
\hline USFWS & U.S. Fish and Wildlife Service \\
\hline
\end{tabular}


$\mu \mathrm{T}$

$\mu \mathrm{V}$

Vmr

WEC microtesla(s)

microvolt(s)

maximum-range speed(s)

wave energy conversion 


\section{Contents}

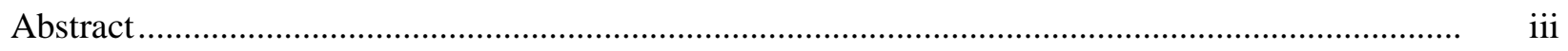

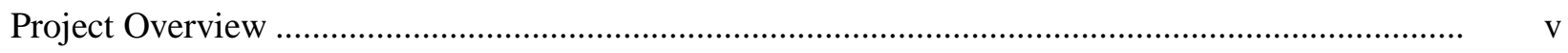

Acronyms and Abbreviations .......................................................................................................... vii

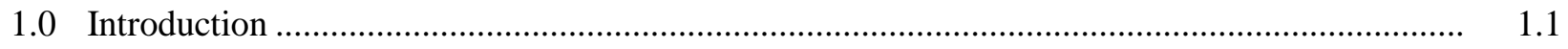

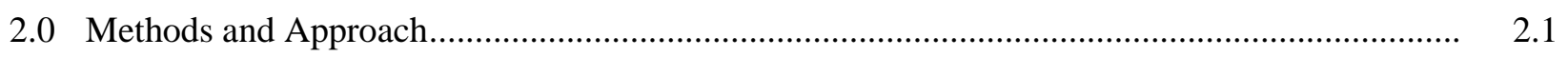

2.1 Literature Search ...................................................................................................... 2.1

2.2 Proposed Wave Park Study Site ................................................................................. 2.1

3.0 Marbled Murrelet Case Study ....................................................................................

3.1 Marbled Murrelet General Biology ................................................................................. 3.11

3.2 Status and Threats to Marbled Murrelets .......................................................................... 3.12

3.3 Marbled Murrelet Marine Abundance and Habitat Use .................................................. 3.12

3.4 Marbled Murrelet Flight.................................................................................................. 3.14

3.5 Marbled Murrelet Diving and Foraging Patterns .......................................................... 3.15

3.6 Marbled Murrelet Diet ......................................................................................... 3.16

3.7 Marbled Murrelet Predators …........................................................................................... 3.16

3.8 Putting It All Together ............................................................................................. 3.17

3.9 Coastal Wave Parks Should Not Adversely Affect Marbled Murrelets............................. 3.18

4.0 Green Sturgeon Case Study ................................................................................................

4.1 Green Sturgeon General Biology ................................................................................... 4.7

4.2 Status and Threats to Green Sturgeons......................................................................

4.3 Green Sturgeon Marine Abundance and Habitat Use ...................................................... 4.9

4.4 Green Sturgeon Population Genetics ........................................................................... 4.10

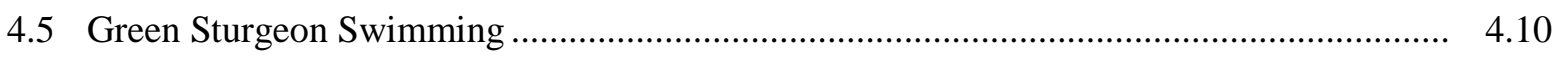

4.6 Green Sturgeon Diet................................................................................................... 4.11

4.7 Green Sturgeon and Electromagnetic Fields ................................................................... 4.11

4.8 Putting It All Together ............................................................................................ 4.11

4.9 Coastal Wave Parks Should Not Adversely Affect Green Sturgeons ............................... 4.12

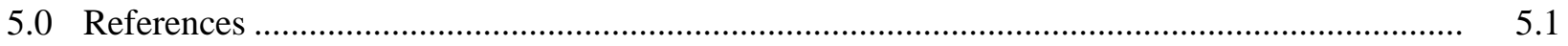




\section{Figures}

2.1 Plan view of the proposed wave park at Reedsport, Oregon ................................................... 2.2

2.2 Mooring schematic for a wave buoy at the proposed wave park at Reedsport, Oregon ............... 2.3

3.1 The six geographic areas identified as marbled murrelet conservation zones in the recovery plan for the species..................................................................................... 3.14

3.2 The marbled murrelet (Brachyramphus marmoratus) ............................................................... 3.20

4.1 Designated critical habitat in Oregon and Washington for the green sturgeon

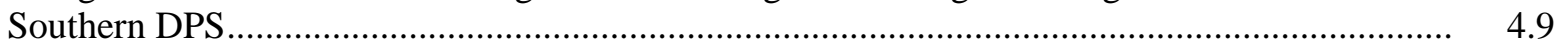

4.2 The green sturgeon (Acipenser medirostris) ..........................................................................

\section{Tables}

3.1 Reviewed literature that discusses the potential effects of marine wave parks on seabirds

3.2 Reviewed literature relevant to the status and biology of the marbled murrelet (Brachyramphus marmoratus).

4.1 Reviewed literature that discusses the potential effects of marine wave parks on fish

4.2 Reviewed literature relevant to the potential effects of the placement of marine hydrokinetic devices on green sturgeon 


\subsection{Introduction}

During the first year of the project, Pacific Northwest National Laboratory (PNNL) project staff performed a literature survey and review as part of Task 2.1.3, Effects on Aquatic Organisms, to develop information with which to assess risk of adverse outcomes associated with physical interaction with marine hydrokinetic (MHK) devices (Subtask 2.1.3.6). For the second year, staff compiled the information so that it could be used to identify expressed concerns over MHK development, identified what types of information would be needed to address the concerns, and performed additional searches as need to gather the information. Staff then developed the information into a specific case study focused on one issue to serve as a model for how other issues could be addressed and ultimately be conveyed to a broad audience. For the third year, the case study approach was expanded to include addressing concerns on the effects of wave energy developments on marbled murrelets and green sturgeons. This report documents those activities.

The methods and approach used to conduct the survey and review are detailed in Section 2. In Section 3, a case study of the potential effects of coastal wave energy parks on marbled murrelets is developed. Section 4 a case study of the potential effects of coastal wave energy parks on green sturgeons is developed. Section 5 is a listing of the full citations for the reviewed articles. 



\subsection{Methods and Approach}

\subsection{Literature Search}

A literature search was conducted by using the Web of Science ${ }^{\circledR}$ component of the ISI Web of Knowledge $^{\mathrm{SM}}$ databases to identify recent articles that would be useful to help assess the potential environmental effects of renewable energy development in the ocean, with an emphasis on seabirds and fish. Several relatively recent general review articles that included possible effects of marine renewable energy devices on seabirds and fish were examined to begin the search process (e.g., Boehlert et al. 2008, Nelson 2008, Thompson et al. 2008, Boehlert and Gill 2010, Grecian et al. 2010, and Langton et al. 2011). From these articles, several general topics of potential environmental effects on seabirds (Section 3) and fish (Section 4) were derived. These topics were used as the primary search factors. Searches were conducted with reference to the potential effects of offshore wave parks on seabirds and fish. Additional sources were identified by cross-checking the Web of Science databases for articles that cited the review articles. It also became clear that the potential effects frequently were offered as hypotheses that often were not well supported by the presentation of appropriate documentation. Therefore, the literature search was refined and focused on trying to obtain the necessary information to support or challenge a proposed potential effect or a specific concern.

The literature search focused on identifying published or gray literature studies that could provide information to evaluate expressed concerns on seabirds and fish. The results were developed into two technical case studies that evaluated the potential effects of the placement of wave parks in coastal waters on the marbled murrelet (Brachyramphus marmoratus; Section 3) and the green sturgeon (Acipenser medirostris; Section 4). Each case study was rewritten into more general form that would be suitable for a broader audience.

\subsection{Proposed Wave Park Study Site}

The first step in evaluating the potential effects of a coastal wave park on marbled murrelets and green sturgeon was to identify the location, distance from shore, water depth at the site, and the size of the proposed Oregon wave park. This information was available in the environmental assessment prepared per the National Environmental Policy Act of 1969 and the Federal Energy Regulatory Commission (FERC) regulations, 18 CFR Part 380 (Order No. 486, 52 FR 47897) as part of the licensing procedure for the park (FERC 2010).

The wave park proposed by Reedsport OPT Wave Park, LLC (OPT) for the Oregon coast would be located $2.5 \mathrm{nmi}$ (4.6 km) off Reedsport, Oregon (FERC 2010). The park eventually would contain 10 wave buoys spaced $100 \mathrm{~m}$ (330 ft) apart encompassing an area of 30 ac (12.1 ha; Figure 2.1). The width of the park presented to the migrating seabirds or fish probably would be no more than $1000 \mathrm{ft}$ (305 $\mathrm{m}$ ). Water depths at the proposed park site range from 165 to $225 \mathrm{ft}$ (50 to $69 \mathrm{~m}$ ), although most of the project structures probably would be deeper than $204 \mathrm{ft}$ (62 m; FERC 2012). Three 160-ft (49-m) catenary lines would moor each power buoy to 3 of 16 anchors in the array via subsurface floats placed at water depths of 30 to $50 \mathrm{ft}$ ( 9 to $15 \mathrm{~m}$ ); 105-ft (32-m) tendon lines will run from the float to the anchor on the seabed (Figure 2.2). Each wave buoy would have a maximum diameter of $36 \mathrm{ft}(11 \mathrm{~m})$, extend $29.5 \mathrm{ft}(9 \mathrm{~m})$ above water, and have a draft of $115 \mathrm{ft}(35 \mathrm{~m})$. Each wave buoy would be connected to an underwater 
substation pod via a power/fiber optic cable that is connected to a subsurface float and descends to the bottom in a lazy S pattern (FERC 2010). The power/fiber optic cables and mooring lines would be 2 to 3 in. (5 to $8 \mathrm{~cm}$ ) and 5 to 6 in. (13 to $15 \mathrm{~cm}$ ) in diameter, respectively. The power/fiber optic cables would be relatively inflexible, and tension on the mooring lines would be several tons. During operations, noise would be generated by the array from waves hitting the buoy float, hydraulic cylinder cycling, hydraulic motor spinning, mooring cable vibration (i.e., strumming), and transfer of vibration from the wave buoys' superstructure into the water. These should produce an overall underwater sound level in the range of about 115 to $125 \mathrm{~dB}$ (FERC 2010). Generated power would be carried to shore via an armored subsea transmission cable, buried in the seabed to a depth of 3 to $6 \mathrm{ft}$ (0.9 to $1.8 \mathrm{~m}$; FERC 2010). The cable would extend from the underwater substation pod to the outlet of an existing wastewater discharge pipeline about $0.5 \mathrm{mi}(0.8 \mathrm{~km})$ from shore. The subsea cable would enter the discharge pipeline and extend through the pipeline passing under the nearshore area, beach, and dunes.

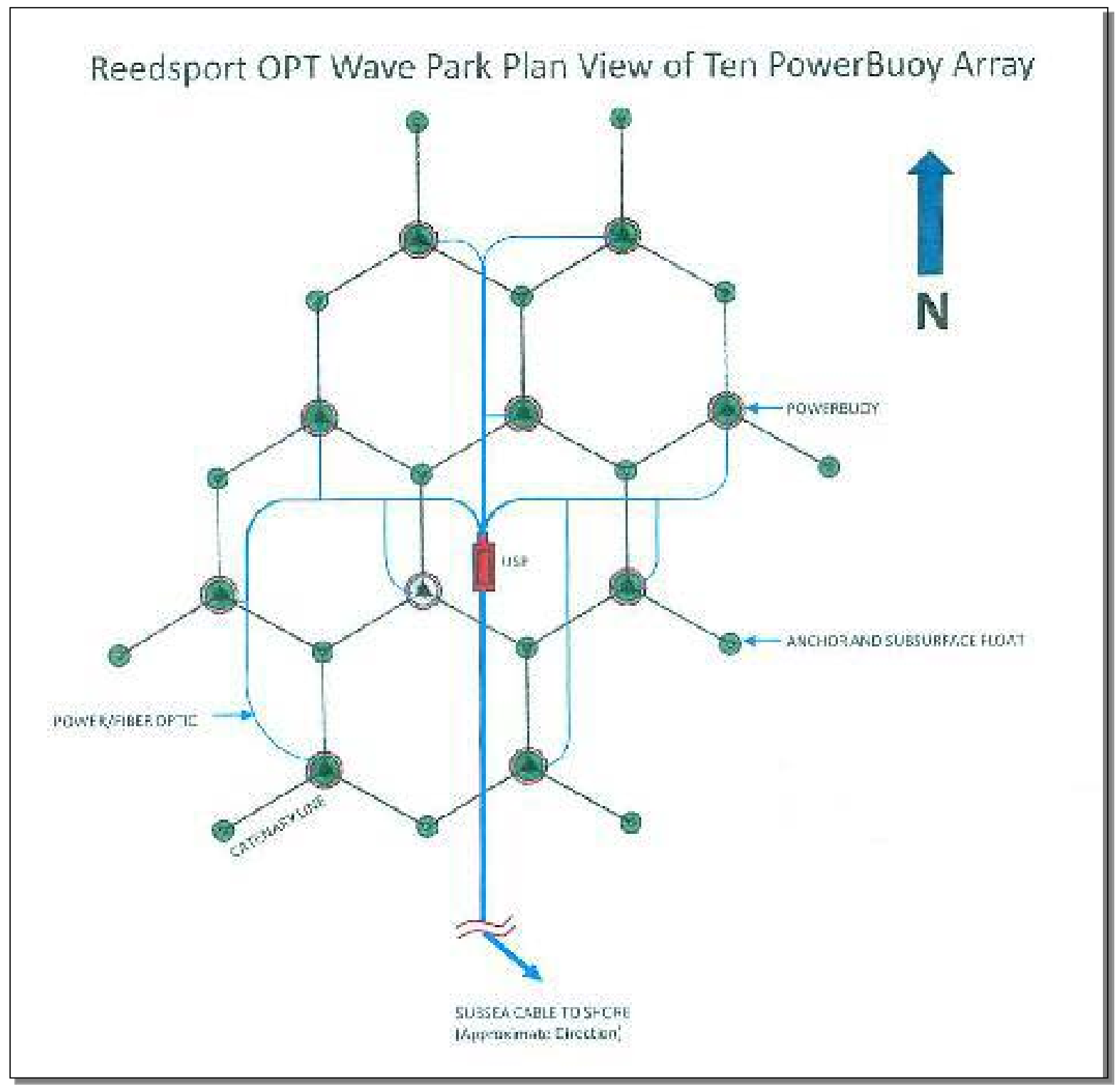

Figure 2.1. Plan view of the proposed wave park at Reedsport, Oregon (FERC 2010). 
FERC (2010) reported that the wave buoys would produce power at frequencies between 0.083 and $0.125 \mathrm{~Hz}$, which would be rectified to $60 \mathrm{~Hz}$ before being transmitted to shore. FERC stated that the proposed enclosed steel structure of the wave buoys and underwater subsea pod would act as Faraday cages that would shield objects from electromagnetic radiation and eliminate or reduce emitted electromagnetic emissions and that this shielding should limit the electric-field (E-field) radiation emitted by the wave buoys and underwater subsea pod. FERC did not provide direct evidence to support these statements. FERC also stated that the transmission cables would have metallic sheathing and would be ground, which would significantly reduce or eliminate E-fields from being emitted into the surrounding aquatic environment (Gill et al. 2012). The project would emit some magnetic-field (B-field) and and induced electric-field (iE-field) radiation. The latter can be generated as animals pass through the B-field (Gill et al. 2012). FERC did not provide an estimates of the EMF emissions that would be expected from the proposed wave park but used an indirect approach to reach its conclusion. The USACE (2004) estimated that emissions from the cables for the Cape Wind project would decrease to about 10 percent of maximum within 10 to $20 \mathrm{ft}$ above the cable and to about 20 to 30 percent of maximum about $10 \mathrm{ft}$ from the cable along the seafloor. FERC (2010) stated that the Cape Wind cables would carry much more power than the wave park cables and concluded that the effects of emissions from the wave park cables would be short term and minor because the $\mathrm{B}$ and $\mathrm{iE}$ fields should decrease rapidly with distance from the cable. Another factor that should be considered is that there would be several cables traversing the sea floor once the entire wave park was completed. The effects of this cable complex could be to cancel out some of the emissions when the fields are $180^{\circ}$ out of phase (Gill et al. 2012). Alternatively, emissions could be combined additively when when they are in phase.

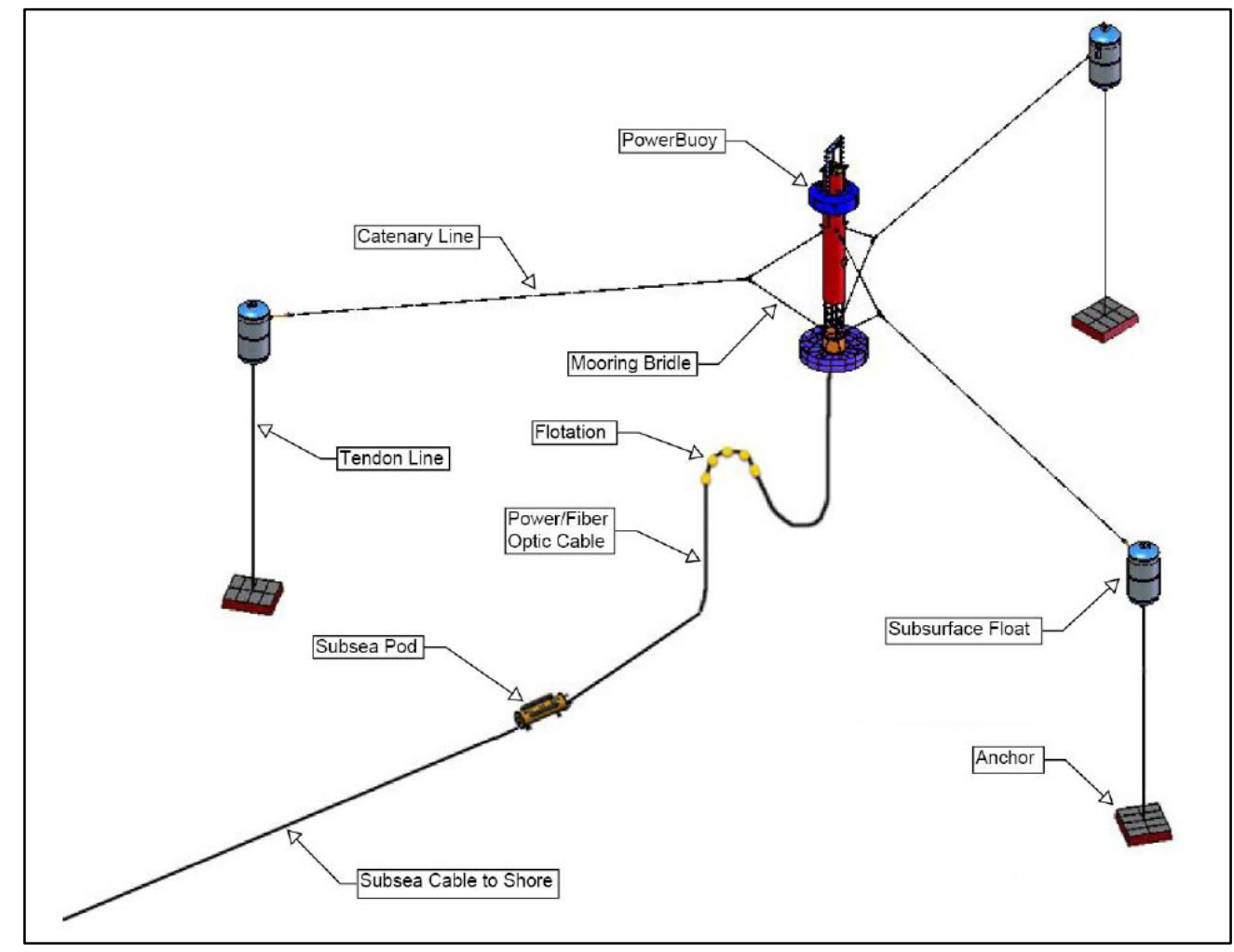

Figure 2.2. Mooring schematic for a wave buoy at the proposed wave park at Reedsport, Oregon (FERC 2012). 
FERC issued an original license for the Reedsport project on August 13, 2012 (FERC 2012). The license contains several requirements "...to protect and enhance fish, wildlife, cultural, socioeconomic, and aesthetic resources at the project.” A license requirement to protect seabirds states that OPT is to develop a final navigation lighting design 1) to limit the potential for attracting migrating birds and to prevent bird collisions with project infrastructure and 2) to implement its proposed plan to monitor for potential project effects on offshore birds. FERC (2010) concluded that the project was likely to adversely affect marbled murrelets. The U.S. Fish and Wildlife Service (USFWS) issued a biological opinion that agreed that the project is likely to adversely affect the marbled murrelet but concluded that the project is not likely to jeopardize the continued existence of the species (FERC 2012). However, the biological opinion included an incidental take statement with one reasonable and prudent measure (RPM) to minimize take of marbled murrelet along with one term and condition to implement the measure. FERC (2012) made the RPM and the incidental take term and condition part of the license and included them in Appendix C of the license. The USFWS also included two discretionary conservation recommendations to further the conservation and protection of marbled murrelets that were not adopted as a part of the license requirements. FERC (2010) concluded that the project was not likely to affect green sturgeon. 


\subsection{Marbled Murrelet Case Study}

The articles summarized in this section were derived from the original general literature search to determine the primary topics of concern regarding the potential effects of MHK devices on seabirds and a focused literature search concerning marbled murrelets (Brachyramphus marmoratus). The possible effects of marine renewable energy devices on seabirds as listed in key review articles (e.g., Boehlert et al. 2008; Thompson et al. 2008; Boehlert and Gill 2010; Grecian et al. 2010; Langton et al. 2011) were examined to begin the search process (Table 3.1). Within these review articles, several potential factors by which wave farms could affect seabirds appeared consistently. Probably the most important direct effect of MHK wave parks on seabirds is potential injury or mortality resulting from collisions with above-water structures. Collisions with underwater structural elements constitute another risk for some diving bird species. Another potential direct effect is the increase in energy expenditure by seabirds that have to fly farther to forage to avoid wave parks that were placed within normal feeding areas. Increased energy expenditures could negatively affect seabird survival and reproduction. The primary indirect effect of wave parks on seabirds is related to potential changes in food web dynamics. Wave parks would often be placed in areas where there is typically little hard substrate. The introduction of novel hard substrate into coastal waters eventually contributes to the development of new biological communities in the area. During the establishment of a wave park, some soft-bottom habitat would be replaced by hard structures. MHK wave devices also could attract species of fish, particularly small species that are often the main prey of seabirds. These changes could affect the dynamics of local food webs. Although the concentration of prey in a relatively small area might seem to be a positive effect on seabirds, such concentrations could attract more seabirds that typically feed in an area, which could lead to increased competition among species and individual birds and may attract potential seabird predators.

Table 3.1. Reviewed literature that discusses the potential effects of marine wave parks on seabirds. The scientific names of some species mentioned in the table are provided in the text.

\begin{tabular}{lc}
\hline \multicolumn{1}{c}{ Summary (Key Points in Boldface Italics) } & Reference \\
\hline $\begin{array}{l}\text { The authors characterized the main potential direct effects of wave device structures } \\
\text { on seabirds as injury and mortality from collisions with structures and the attraction }\end{array}$ & Boehlert et al. (2008) \\
to or avoidance of a habitat area. Indirect effects include changes in bird habitat or & \\
food webs. The authors concluded that the potential for collisions with above-water & \\
structures represented the greatest risk to seabirds. Potential changes to coastal & \\
marine food webs was the main indirect risk to seabirds. Wave devices introduce & \\
novel stressors to seabirds via the placement of above-water structures, the use of & \\
continuous lighting, and the possible discharge of pollutants. The risks are greatest & \\
when devices are located within key migratory pathways. The authors ranked & \\
various potential effects on 15 groups of seabirds. & \\
\hline
\end{tabular}




\begin{tabular}{|c|c|}
\hline Summary (Key Points in Boldface Italics) & Reference \\
\hline $\begin{array}{l}\text { Potential risks for seabirds include collision, disturbance of breeding colonies, } \\
\text { fouling by release of oil or hydraulic fluids, and changes in prey populations. Year- } \\
\text { round residents, such as common murres (Uria aalge), cormorants (Phalacrocorax } \\
\text { penicillatus and P. pelagicus), and marbled murrelets have the greatest chance of } \\
\text { negative interaction. The structure, density, and arrangement of wave devices may } \\
\text { affect potential seabird food resources. Floating buoys may provide shelter similar to } \\
\text { a kelp raft, and an array of mooring cables may imitate the fundamental form of a } \\
\text { kelp forest. Wave devices may serve as nursery grounds for large fish juveniles, such } \\
\text { as rockfish (Sebastes spp.), or may attract forage fish, such as northern anchovy, } \\
\text { Pacific sardine, or Pacific herring, which may enhance food resources for seabirds. } \\
\text { Marbled murrelets have high potential for interaction with wave devices because they } \\
\text { occupy nearshore habitats. Murrelets fly fast and low over the water but are agile. } \\
\text { Nonetheless, collision potential is high. }\end{array}$ & Thompson et al. (2008) \\
\hline $\begin{array}{l}\text { In a general review of the environmental effects of marine renewable energy devices, } \\
\text { the authors evaluated the effects of wave energy devises on marine organisms by } \\
\text { considering the properties of the devices-physical presence, dynamics, acoustics, } \\
\text { chemicals, and electromagnetic field (EMF) emissions. The authors listed the } \\
\text { primary effect of wave devices on seabirds as above-water collisions. Seabirds may } \\
\text { expend extra energy to avoid wave device arrays during foraging or migratory } \\
\text { flights. The authors mentioned the diving birds face possible entanglement in } \\
\text { underwater cables or collisions with underwater structural components. The } \\
\text { authors did not discussion potential acoustic or EMF interactions with seabirds. } \\
\text { Wave devices may attract prey species consumed by some seabirds and may provide } \\
\text { resting sites for birds. }\end{array}$ & Boehlert and Gill (2010) \\
\hline $\begin{array}{l}\text { The authors explored the possible consequences of increased use of marine } \\
\text { renewable energy installations (MREIs) for seabirds. Direct negative effects include } \\
\text { risk of collision, disturbance, displacement and redirection during construction, } \\
\text { operation and decommissioning. Above-water collision with wind-powered devices } \\
\text { is a concern but is not as significant for low-profile wave-powered devices. Wave } \\
\text { devices introduce the possibility of underwater collisions and could affect marine } \\
\text { birds by altering oceanographic processes that determine food availability. } \\
\text { Conversely, wave-powered MREIs could enhance seabird habitats by providing bird } \\
\text { roosting sites and underwater substrates that aggregate prey. The net result could } \\
\text { improve and protect foraging opportunities for marine birds, albeit with the } \\
\text { possible risk of underwater collisions with structures. }\end{array}$ & Grecian et al. (2010) \\
\hline $\begin{array}{l}\text { The authors summarized the possible effects of tidal stream and wave power } \\
\text { generation activity in Scottish Waters on seabirds. The authors evaluated potential } \\
\text { increased rates of energy acquisition (e.g., greater prey abundance) or expenditure } \\
\text { (e.g., increased foraging distance if birds avoid developments placed in normal } \\
\text { feeding areas). Energy budget changes could affect reproduction and survival. The } \\
\text { authors stated that susceptibility to the effects of tidal stream and wave development } \\
\text { probably depends on each species' foraging method, flight behavior, and ability to } \\
\text { withstand environmental fluctuations. }\end{array}$ & Langton et al. (2011) \\
\hline $\begin{array}{l}\text { FERC concluded that the proposed action is likely to adversely affect the marbled } \\
\text { murrelet, but it would have no effect on critical habitat for marbled murrelet. FERC } \\
\text { also concluded that the potential for the project to adversely affect marbled murrelets } \\
\text { is low, due to project design and configuration. The spacing of the buoys } 330 \mathrm{ft} \text { apart } \\
\text { should provide room for birds to safely maneuver between them. The } 29.5-\mathrm{ff}-\mathrm{high} \\
\text { PowerBuoys have a relatively low profile (in comparison to offshore wind turbines } \\
\text { that may be six times taller), which could minimize the risk that murrelets } \\
\text { approaching the project area from terrestrial habitats would collide with them. }\end{array}$ & FERC (2010) \\
\hline
\end{tabular}


From these review articles, several general topics of potential environmental effects on seabirds were derived. Key points or effects identified by each reviewed paper (boldface italics), and their relevance to the evaluation of the effects of wave parks on marbled murrelets, are captured in Table 3.2, which also includes a citation to the appropriate source as listed in Section 5 (References).

Table 3.2. Reviewed literature relevant to the status and biology of the marbled murrelet (Brachyramphus marmoratus). The scientific names of species mentioned in the table are provided in the text.

\begin{tabular}{|c|c|c|}
\hline $\begin{array}{l}\text { Marbled } \\
\text { Murrelet }\end{array}$ & Summary (Key Points in Boldface Italics) & Reference \\
\hline Status & $\begin{array}{l}\text { The USFWS originally listed the marbled murrelet as federally threatened on } \\
\text { October 1, 1992, for Washington, Oregon, and California distinct population } \\
\text { segments. The USFWS originally designated critical habitat for the marbled } \\
\text { murrelet in Washington, Oregon, and California on May 24, 1996, and revised } \\
\text { the critical habitat on October 5, 2011. The USFWS developed a recovery plan } \\
\text { in 1997. The Washington, Oregon, and California murrelet population is a } \\
\text { distinct population segment according to the } 1996 \text { DPS Policy. The continental } \\
\text { United States has a much smaller murrelet population (about } 16,700 \text { birds; } \\
\text { Falxa et al. 2011) than does Canada (median population 66,000 birds; Burger } \\
\text { 2002). }\end{array}$ & USFWS (2009) \\
\hline $\begin{array}{l}\text { Population } \\
\text { Size }\end{array}$ & $\begin{array}{l}\text { Miller et al. estimated that in 2004, the population size of marbled murrelets } \\
\text { at sea was about 22,000 birds (on any single day) for the coastal waters } \\
\text { adjacent to northwestern California, western Oregon, and western } \\
\text { Washington. They recorded the highest densities of murrelets along the } \\
\text { Oregon and northernmost California coasts and the lowest densities along the } \\
\text { California coast from the Humboldt-Mendocino County line to just south of } \\
\text { San Francisco Bay. The highest murrelet population occurred in Puget Sound } \\
\text { and the Straits of Juan de Fuca. }\end{array}$ & Miller et al. (2006) \\
\hline $\begin{array}{l}\text { Population } \\
\text { Size }\end{array}$ & 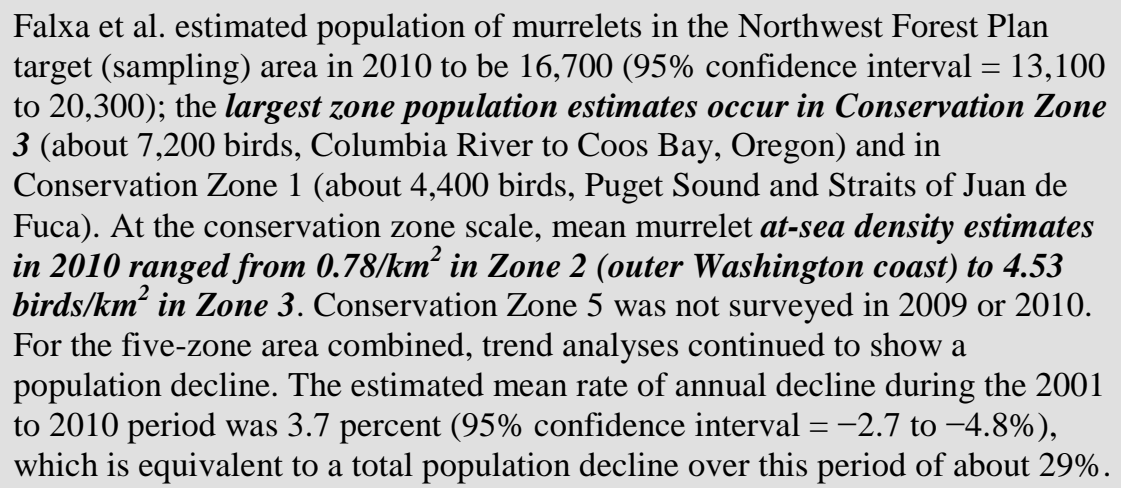 & Falxa et al. (2011) \\
\hline
\end{tabular}


Threats

\begin{tabular}{|c|c|}
\hline $\begin{array}{l}\text { Critical } \\
\text { Habitat }\end{array}$ & $\begin{array}{l}\text { The USFWS revised critical habitat for marbled murrelet on October 5, 2011, } \\
\text { for areas in Oregon and northern California. Critical habitat includes forested } \\
\text { areas that approach the coast in Tillamook, Lincoln (south of Newport), } \\
\text { Lane, and Douglas counties. }\end{array}$ \\
\hline $\begin{array}{l}\text { General } \\
\text { Biology }\end{array}$ & $\begin{array}{l}\text { Nelson et al. review marbled murrelet general biology. They noted that } \\
\text { predation causes } 78 \text { percent of the nest failures for nests with known } \\
\text { outcomes. The common raven and Steller's jay have are the primary } \\
\text { predators of active murrelet nests. Increases in the amount of forest edge } \\
\text { increase murrelet nest predation vulnerability. The authors did not mention at- } \\
\text { sea predation. Marbled murrelets spend more than } \mathbf{9 0 \%} \text { of their time at sea. } \\
\text { They usually occur in sheltered nearshore waters within } 3 \text { mi of shore. } \\
\text { Murrelets are highly mobile and can change foraging sites within the breeding } \\
\text { season in response to environmental changes. For example, murrelets changed } \\
\text { their foraging behavior and habitat selection within a } 100-k m \text { (62-mi) area } \\
\text { within days or weeks in response to small-scale variability in upwelling } \\
\text { intensity and prey availability. }\end{array}$ \\
\hline
\end{tabular}

General

Biology

The Recovery Implementation Team (RIT) identified five main factors that are contributing to marbled murrelet population declines. The factors are terrestrial (forest) nesting habitat loss; predation on murrelet eggs and chicks in their nests; changes in marine prey abundance, distribution, and quality; post-fledging mortality; and cumulative and interactive effects. The RIT used several assumption in evaluating threats to marbled murrelets-birds nest where they nested the previous year, and if the stand is cut, those birds may not breed again; juvenile:adult ratios are about 0.03 to 0.08 versus the ratio of 0.2 required for a stable population; predator populations, including avian (corvids and raptors) and mammals (e.g., squirrels, mice) that probably prey on chicks and eggs, may be increasing; population growth is most sensitive to adult survival rates; and prey species include juvenile rockfish, smelt, herring, anchovies, sardines, sand lance, squid, juvenile salmon, and krill.

The authors answered key questions about the potential effects of building wind turbines at Radar Ridge, southwest Washington on the marbled murrelet. They determined that marbled murrelets use the Radar Ridge area, flying at an average elevation of $355 \mathrm{~m}$. They also estimated the 87 collisions were likely to occur annually, which equals 2625 collisions over the 30 -year life of the wind farm. Nelson et al. concluded that the risk of collision was high.

Piatt et al. reviewed marbled murrelet status in Alaska and British Columbia, providing information about the species' general biology. Marbled murrelets belong to the family Alcidae and are one of three species in genus Brachyramphus. These birds breed only from California to Alaska in western North America. Marbled murrelets are fairly small birds with body lengths of about 23 to $25 \mathrm{~cm}$, wing lengths of about 122 to $149 \mathrm{~mm}$, and adult weights that range to 188 to $269 \mathrm{~g}$. Principal prey during the summer are small schooling fish, including Pacific sand lance, northern anchovies, Pacific herring, and capelin. Invertebrates (e.g., euphausiids and mysids) are more common in their diets during the winter and spring. Although marbled murrelets use wing-propelled diving to chase prey under water, they can still fly. Murrelet wing area is reduced to decrease underwater drag, its breast muscles are well-developed for underwater locomotion, and the body mass to wing area ratio (wing-loading) is high. Marbled murrelets have a rapid, flapping aerial flight and use high flight speeds to maintain lift and stay airborne.
Recovery Implementation Team (2012)

Nelson et al. (2009)

76 FR 61599

Nelson et al. (2006)

Piatt et al. (2006) 

weak association between murrelet abundance and tidal flat shorelines.

At-Sea

Speckman et al. determined that $82 \%$ (81 of 99) the fish identified in the bills of fish-holding adult murrelets during their study in Alaska were Pacific sand lance. The number of adult murrelets holding fish was significantly higher in the evening than at any other time of day. Fledgling numbers did not vary significantly with time of day, indicating that juveniles were moving into and out of the study area during the day. Murrelets usually occurred in groups of two or more birds, even during incubation. The authors did not find a correlation between the number of murrelets on the water and the number of murrelet detected in adjacent forests.

At-Sea Yen et al. studied the relationships between marbled murrelet marine distribution and abundance to abiotic and biotic marine environmental features in coastal British Columbia. The authors found that murrelet density was higher near sandy substrate, estuaries, and where water temperatures were cooler. Murrelet density was lower near herring spawn areas and glaciers. Variables used in the model included sea surface temperature, herring spawn index, estuary locations, distribution of sand and fine gravel substrates (as a proxy for sand lance distribution), and proximity to glaciers. Yen et al. used the model Tree-SPLUS to predict the maximum carrying capacity of 170,500 birds for the marine habitat of coastal British Columbia. An additional a posteriori predictor, the shortest distance to old-growth forest, explained much of the remaining residual variance. This model result led to a hypothesis of how marbled murrelet distribution and abundance relates to proximity to oldgrowth forests, and it makes an initial basic link between the marine and terrestrial aspects of marbled murrelet habitat.

$\begin{array}{ll}\text { At-Sea } & \text { Burger et al. studied seabird densities and spatial aggregations during summer } \\ \text { off Vancouver Island, British Columbia. Marbled murrelets densities were } & \begin{array}{l}\text { Burger et al. } \\ \text { (2008) }\end{array} \\ \sim 45.2 / \mathrm{km}^{2} \text { inshore and } 10.6 / \mathrm{km}^{2} \text { offshore, which were among the highest at } \\ \text { sea densities reported for the species. Almost all murrelets were within } 2.0 \mathbf{~ k m} \\ \text { of shore; }>\text { 75\% were within } \mathbf{0 . 6} \mathbf{~ k m} \text { of shore. Murrelets were usually in water } \\ <20 \text { m deep and occurred in certain coastal sectors year to year. At the small } \\ \text { scales }(\sim 280 \text { m), murrelets seldom encountered murres or auklets. Murrelet } \\ \text { occurrence patterns may reflect species-specific differences in foraging } \\ \text { strategies and habitat preferences among the species or may result from } \\ \text { interspecific competition. Most murrelets had left the study area by mid- } \\ \text { August. The exodus was not related to prey density but probably competition } \\ \text { with murres and auklets. }\end{array}$


At-Sea

At-Sea

At-Sea /

Juveniles
Hébert and Golightly tracked 102 marbled murrelets in northern California coastal waters from 2001 to 2003. They detected murrelets at an average of $1.4 \pm 0.1 \mathbf{~ k m}$ from shore, regardless of sex or nesting status. Murrelets traveled less than $99.1 \pm 9.5 \mathrm{~km}$ along shore. Male murrelets tended to travel farther than females; non-nesting males traveled farther than males that nested after capture. The authors found that murrelet home range averaged $505 \pm 75 \mathbf{k m}^{2}$. Home-range size was larger for males than females and for non-nesting than nesting murrelets. Home-range size was larger for non-nesting than for nesting males but was similar for non-nesting and nesting females. The study showed that marbled murrelets in northern California occurred nearshore and traveled less than $50 \mathrm{~km}$ from the mouth of Redwood Creek, the watershed where most nesting occurred.

Ronconi and Burger studied marbled murrelet foraging behavior at Vancouver Island, British Columbia. Murrelets increased diving activity when prey was scarce and oceanographic conditions were poor but decreased diving activity where prey availability was high. The relationship between food availability and diving activity was linear. The authors found that murrelets increased foraging effort in 2005, but the increase was not enough to ensure average levels of reproductive success. Therefore, extremely poor environmental conditions might limit murrelet reproductive success despite the birds' flexible foraging behavior.

Wong et al. studied newly fledged juvenile and adult marbled murrelet marine distribution and behavior off southwest Vancouver Island, British Columbia. The authors found that juveniles were associated with adults at fine scales (1$100 \mathrm{~m}$ ), although they were significantly closer to shore than adults. Juvenile and adult daily distributions overlapped at coarse scales (1-10 km) but overlapped less with annually averaged distributions. Juveniles usually foraged alone, but adults foraged in pairs or larger groups. The results indicated that monitoring juvenile-to-adult ratios to indicate breeding success does not need to consider possible nursery areas, but monitoring must consistently include waters closest to the shore because juveniles stay near the shoreline.

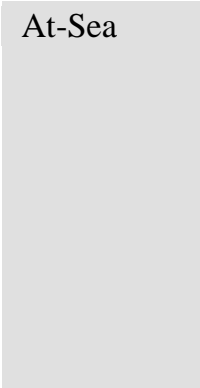

At-Sea
The authors found that in 2007, murrelets in southeast Alaska moved from a shallower, more sheltered inner region, used during the day for foraging and staging for inland flights (day:night densities $=172 \pm 67$ and $15 \pm 13$ murrelets $\mathrm{km}^{-2}$ ) to a deeper, more exposed outer region, further from shore, during dark hours (day:night densities $=41 \pm 23$ and $113 \pm 61$ murrelets $\cdot \mathrm{km}^{-2}$ ). Prey school density and relative prey density were significantly higher at night in the inner region versus the outer region, suggesting that murrelets were not moving to forage on fish prey. The authors speculated that murrelets move from day use areas to night use areas is to avoid predators such as bald eagles, great horned owls, and mammals.

Haynes et al. found that in Alaska, the distance to flyways was most important in explaining at-sea distribution at most fine scales ( $<1600 \mathrm{~m})$; prey variables became more important as scale increased. At a larger scale $(14.4 \mathrm{~km})$, the authors found that low prey availability was associated with lower densities of murrelets. There was an interaction with breeding period, however; under conditions of low prey availability, murrelets were more abundant during incubation and chick-rearing than during nest initiation and post-breeding, suggesting that murrelets remained close to nesting habitat during periods requiring frequent inland flights.
Hébert and Golightly (2008)

Ronconi and Burger (2008)

Wong et al. (2008)

Haynes et al. (2010)

Haynes et al. (2011) 


\begin{tabular}{|c|c|c|}
\hline $\begin{array}{l}\text { At-Sea/ } \\
\text { Diet }\end{array}$ & $\begin{array}{l}\text { Strong studies seabird distribution at and near Clatsop Spit near the mouth of } \\
\text { the Columbia River. He found that marbled murrelets were rare in the region } \\
\text { but occurred around the South Jetty (north and south sides within } 500 \mathrm{~m} \text { of the } \\
\text { structure, at depths of } 6 \text { to } 20 \mathrm{~m} \text { ) with a higher consistency and density than } \\
\text { adjacent nearshore waters down the coast. Murrelets occurred in the area } \\
\text { only in summer (May-August); density ranged from } 4.1 \text { to } 5.6 / \mathbf{k m}^{2} \text { at the } \\
\text { jetty and from } 1.0 \text { to } 2.3 / \mathrm{km}^{2} \text { at distances up to } 20 \mathrm{~km} \text { south of the jetty. Like } \\
\text { other alcids, marbled murrelets are pursuit divers, and some evidence suggests } \\
\text { they forage near or at the bottom. Evidence suggested that murrelets fed } \\
\text { mainly on Pacific sand lance, foraged alone or in paired foraging groups, and } \\
\text { tended to be located where waters were less than } 25 \mathrm{~m} \text { deep. Murrelets were } \\
\text { never found in mixed foraging groups that included other seabirds. }\end{array}$ & Strong 2005 \\
\hline Nesting & $\begin{array}{l}\text { Hébert et al. found that in Redwood National and State Parks, Humboldt } \\
\text { County, northern California, in } 2001 \text { to 2003, marbled murrelet mean nest } \\
\text { initiation dates ranged from late May to early June. Egg laying occurred prior } \\
\text { to 06:30 AM, and males took the first incubation shift. Most murrelets (67\%) } \\
\text { exhibited 24-h incubation bouts followed by } 24 \text { h at sea. Most of the remaining } \\
\text { showed an irregular incubation pattern by missing at least one day within the } \\
\text { first five days of incubation. Males and females had similar incubation } \\
\text { patterns, but females with regular incubation patterns were significantly } \\
\text { heavier at capture than females with irregular incubation patterns. Hébert et al. } \\
\text { observed that daily survival probabilities of nests tended to be lower in the } \\
\text { first } 12 \text { days of incubation versus the last } 12 \text { days. Hatching success averaged } \\
\text { about } 38 \% \text {. Hatching success was greater for early nests than later nests. } \\
\text { Nests were more likely to fail earlier in the incubation period than later. } \\
\text { Hatching success was not affected by hatching pattern. }\end{array}$ & $\begin{array}{l}\text { Hébert et al. } \\
\text { (2012) }\end{array}$ \\
\hline $\begin{array}{l}\text { Flight } \\
\text { Patterns/ } \\
\text { Speed }\end{array}$ & $\begin{array}{l}\text { Cooper et al. used radar to measure daily, monthly, and annual patterns of } \\
\text { marbled murrelet abundance and movements at the Olympic Peninsula of } \\
\text { Washington. Landward movements of murrelets peaked from about } 75 \text { min to } \\
\text { about } 20 \text { min before sunrise, followed by a seaward exodus from about } 20 \text { min } \\
\text { before sunrise to about } 65 \text { min after sunrise. Marbled murrelet flight speeds } \\
\text { were slower for landward flights (91 } \mathbf{k m} / \mathbf{h}) \text { than for seaward flights (102 } \\
\mathbf{k m} / \mathbf{h}) \text {. }\end{array}$ & $\begin{array}{l}\text { Cooper et al. } \\
\text { (2001) }\end{array}$ \\
\hline $\begin{array}{l}\text { Flight } \\
\text { Speed }\end{array}$ & $\begin{array}{l}\text { Murrelets fly at speeds up to } 120 \mathrm{~km} / \mathrm{h} \text { when breeding. Murrelets are not } \\
\text { particularly maneuverable flyers because of the high body mass to wing area } \\
\text { ratio (wing loading). }\end{array}$ & $\begin{array}{l}\text { Burger and } \\
\text { Chatwin (2002) }\end{array}$ \\
\hline $\begin{array}{l}\text { Flight } \\
\text { Height }\end{array}$ & $\begin{array}{l}\text { The authors found that the mean height above ground level that murrelets } \\
\text { flew was } \mathbf{2 4 6} \boldsymbol{m} \text {. The lowest murrelet-type target detected was at } 62 \mathrm{~m} \text {. Note } \\
\text { that all flights were over land, not water. }\end{array}$ & $\begin{array}{l}\text { Stumpf et al. } \\
\text { (2011) }\end{array}$ \\
\hline
\end{tabular}


Flight

Speed

Diving

At-Sea /

Foraging

Patterns /

Diving
Elliott et al. measured marbled murrelet flight speeds to determine whether flight speeds of an exceptionably fast bird coincide with the maximum-range speeds (Vmr) predicted by aerodynamic theory. The mean recorded speed was $22.6 \mathrm{~m} / \mathrm{s}$ (50.6 $\mathrm{mph}$ ), which was significantly faster than the $\mathrm{Vmr}$ predicted by four aerodynamic models, using conventional values for the parasite drag coefficient. The drag coefficient required for the models to predict a Vmr of 22 $\mathrm{m} / \mathrm{s}$, were less than any drag coefficient previously reported. The authors concluded that the cruising speed of marbled murrelets exceeds the Vmr predicted by aerodynamic theory. The authors hypothesized that flight speeds exceeded the Vmr to reduce predation rates and to maximize chick growth rates. However, Elliott et al. found no significant difference between flight speeds during low (darkness) and high (daylight) predation periods or between chick-rearing and nonbreeding periods. The authors then evaluated the reliability of aerodynamic theory for marbled murrelets and determined that the current aerodynamic models are insufficient for this exceptionally fastflying bird.

\section{Jodice and Collopy determined that along the Oregon coast, murrelet dive} depths ranged from 3 to $36 \mathrm{~m}$. Dive time generally depended on the need to replenish the bird's oxygen supply. The marbled murrelet is a pursuit-diving seabird, and the duration and depth of its dives are each typically less than the maximum attainable values. There is substantial high individual variability in dive parameter values. The authors found that the mean duration of a dive bout (three or more consecutive dive cycles) was about 28 to $33 \mathrm{~min}$. Most dive bouts occurred in water $<\mathbf{1 0} \mathbf{m}$ deep. There was no significant relationship between dive time and water depth in this study. Therefore, marbled murrelet likely foraged throughout the water column, which is consistent with the habits of their primary prey, the Pacific sand lance. Marbled murrelets used two types of prey-handling behaviors during this study — swallowing prey beneath the water surface on some occasions and while on the water surface at other times.

Peery et al. found murrelets at sea occurred primarily within $2500 \mathrm{~m}$ of the Coast. The authors determined that murrelets in the Año Nuevo Bay area of California were located an average of about $8 \mathrm{~km}$ from the mouths of creeks they used to reach nesting habitat in the Santa Cruz Mountains during the day and about $5 \mathrm{~km}$ from them at night. Non-nesting murrelets spent the night resting near flyways used to reach nesting habitat and foraged during the day an average of $5.7 \mathrm{~km}$ from nighttime locations. However, murrelets travel as far as $300 \mathrm{~km}$ from waters near the Santa Cruz Mountains during October through March (nonbreeding season). Breeding murrelets foraged close to nesting habitat once they began nesting and nest attendance was at a maximum. Actively nesting birds increased dive times by 71 to $73 \%$ by increasing the number of dives. Breeding birds used creeks as flyways to inland nesting habitat where they remained during the day. These birds spent rested during nights near the flyways used to reach nesting habitat, flew inland early in the morning, and then flew to daytime foraging sites several kilometers from nighttime locations. Nonbreeding birds had similar nighttime and daytime distributions that tended to be located farther from inland flyways. These birds often remained near daytime foraging areas located farther from nesting habitat and did not spend the night near flyways. They rarely flew inland. Breeding murrelets dive more while nesting than before or after nesting, or compared to nonbreeding birds. Mean dive time was $23.5 \mathrm{~s}$ $(S D=9.0 \mathrm{~s})$, and mean post-dive surface time was $11.9 \mathrm{~s}(\mathrm{SD}=9.3 \mathrm{~s})$.
Elliott et al. (2004)

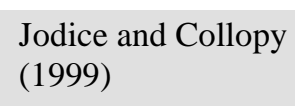

Jodice and Collopy (1999)

Peery et al. (2009) 
Swim

Speeds

Swim

Speeds

Swim

Speeds

Diet
The authors measured wing propulsion during deep diving by Brünnich’s guillemots (Uria lomvia) by using bird-borne data loggers. The birds surged frequently using up- and downstrokes at the beginning of a dive to reach mean speeds of 1.2 to $1.8 \mathrm{~m} / \mathrm{s}$, which was near the expected optimal swim speed. Descending deeper, birds decreased the frequency of surges, relaying only on the downstroke. When ascending, birds stopped stroking at $18 \mathrm{~m}$ depth, but increased swim speed to $2.3 \mathrm{~m} / \mathrm{s}$, possibly because of increasing buoyancy as air volumes expanded.

The authors used data-loggers on free-ranging birds diving to depths of 20 to $30 \cdot \mathrm{m}$ to measure swim speeds and other dive parameters for four species of alcids (600 to $1000 \mathrm{~g}$ weight) and a small penguin species. Watanuki et al. found that alcid swim speed during descent ranged from about 1.1 to $1.6 \mathrm{~m} / \mathrm{s}$. At depths of $20-30 \cdot \mathrm{m}$, all species ascended without wing stroking, averaging speeds of 1.6 to $1.8 \mathrm{~m} / \mathrm{s}$. The birds often increased speed by 0.2 to $0.5 \mathrm{~m} / \mathrm{s}$ during either dive phase.

The authors compiled data from several studies and examined the allometric relationship of swim speed in free-ranging diving birds, mammals, and turtles with body mass (37 species; 0.5-90,000 kg mass) but also considered group phylogenies to account for differences related to behavior and evolutionary history. Relative to diving birds, the authors' data showed general trend for increased speed with increased body size. However, the data also seemed to show that there was little relationship between speed and size when speeds were within the 1 to $2 \mathrm{~m} / \mathrm{s}$ range.

The authors compared stable-isotope signatures of $\delta \mathrm{N}-15$ and $\delta \mathrm{C}-13$ in marbled murrelet feathers of museum specimens collected in central California from 1895 to 1911 with values in feathers collected from 1998 to 2002 . Values of $\delta \mathrm{N}-15$ in pre-breeding diets declined significantly during the past century, which the authors related to a decline in sardine populations. Values of $\delta \mathrm{N}-$ 15 in post-breeding birds were nearly constant. $\delta \mathrm{C}-13$ values in pre-breeding bird diets declined during that time, which suggested that krill were more important in modern diets than in historic pre-breeding bird diets but not in post-breeding bird diets. During cool years when murrelet reproduction was likely to be high, stable-isotope mixing models indicated that the proportion of energetically superior, high-trophic-level prey declined strongly, whereas energetically poor, low-trophic-level and midtrophic-level prey increased in the pre-breeding murrelet diets. Decreased prey resources that caused murrelets to fish lower in the food web appeared partly responsible for poor murrelet reproduction and may have contributed to its general population declines. These changes were likely related to the Pacific sardine fisheries collapse in the late 1940s and the recent declines of similar fisheries in central California.
Watanuki et al. (2003)

Watanuki et al. (2006)

Watanabe et al. (2011)

Becker and Beissinger (2006) 
Diet $\quad$ Becker et al. used stable isotope analyses of $\delta \mathrm{N}-15$ and $\delta \mathrm{C}-13$ in murrelet feathers and prey tissues during the pre- and post-breeding seasons of 1998 to 2002 to evaluate variation in murrelet diets in central California. Isotopic signatures of 10 potential prey species clustered into low, mid, and high trophic level prey groups. Murrelet $\delta N-15$ values and trophic level were lower prior to breeding than after breeding in years when more low trophic level prey (krill) were available. However, pre- and post-breeding bird diets were similar in years when fewer krill were available. Pre-breeding bird diets had lower $\delta \mathrm{C}-13$ values than those of post-breeding birds, which followed the availability of C-13 enriched juvenile rockfish and market squid. Male and female diets did not differ. Murrelet productivity (juvenile:adult ratios) was positively correlated with rockfish and krill abundance. Murrelet productivity was also positively related to the proportion of mid trophic level prey in postbreeding bird diets, and thus negatively related to the proportion of low and high trophic level prey consumed. Becker et al. suggested that cooler local temperatures increase krill and juvenile rockfish availability to murrelets, which improves murrelet reproductive success.

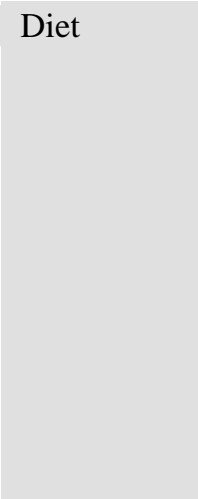

Marbled murrelets feed year-round in nearshore waters of the northeastern Pacific. Norris et al. analyzed stable-carbon and -nitrogen isotopes in feathers of museum specimens collected in the Georgia Basin, British Columbia, to evaluate the influence of changes in diet quality on murrelet populations. They found a decline in stable isotopic signatures between 1889 and 1996 that approximated a $62 \%$ drop in trophic feeding level. The authors determined that during the past 40 years, the proportion of fish in murrelet diets was related closely to murrelet abundance. The authors determined that before the 1950s, murrelet populations in the Georgia Basin could expand and probably were not limited by diet quality. After the 1950s, diet quality often limited murrelet populations. The authors concluded that protecting nesting habitat may not be sufficient to rebuild murrelet populations and that restoring marine habitat quality might benefit recovery.

Diet Janssen et al. investigated relationships between timing of breeding, female body condition and pre-breeding trophic feeding level. The authors identified egg-producing females by elevated yolk precursor (vitellogenin) levels and inferred diets by stable carbon $(\delta 13 \mathrm{C})$ and nitrogen $(\delta 15 \mathrm{~N})$ analysis of murrelet and prey tissues during the pre-breeding seasons in Desolation Sound, British Columbia. The authors found that females were in better condition and were more likely to produce an egg early in the breeding season. However, differences in pre-breeding diet between egg-producing and nonegg-producing females were not consistent among years. The study results suggested egg production and breeding success was inconsistently related to trophic level of prey in the murrelet pre-breeding diet. Janssen et al. suggested that the net energy gain from feeding on a prey type is a function of that prey type's relative availability. Murrelets usually feed chicks single, large subadult or adult fish (e.g., sand lance, immature herring, salmon smolt) that have higher energy value than juvenile and larval age classes of fish.

Predation Malt and Lank compared the fates of 448 simulated murrelet nests at paired edge and interior treatments, at sites with "hard" edges (recent clear cuts), "soft" edges (regenerating forest), and natural edges (i.e., riparian areas) in southwestern British Columbia, Canada. The authors found that nest disturbance probability at hard edge sites was 2.5 times that of interior sites, but soft edge sites had less than half of the disturbance probability of interior sites. There was no edge effect at natural edge sites. The study results suggested that the initial fragmentation effects decrease as forests regenerate. Malt and Lank found that Steller's jays drive patterns of nest predation risk at the regional scale.
Becker et al. (2007)

Norris et al. (2007)

Janssen et al.

(2009)

Malt and Lank (2009) 

murrelet population. The authors noted that reducing predation by $40 \%$ would yield a stable murrelet population if there was a concomitant very slight increase in murrelet after-hatch-year survival from 0.896 to 0.910 . Peery and Henry modeled that controlling predators yielded larger murrelet populations when the maximum number of breeders was allowed to increase during the projection period, but habitat carrying capacity did not affect murrelet extinction risk.

\begin{tabular}{|c|c|c|}
\hline Prey & $\begin{array}{l}\text { Robards and Piatt reviewed the literature on sand lance biology. Pacific sand } \\
\text { lance are elongate fish that grow as long as about } 26 \text { cm (10.2 in.). Sand } \\
\text { lance are abundant in shallow nearshore areas usually in waters less than } 50 \\
\text { m (164 ft) deep and often in as little as } 6 \mathrm{~m} \text { ( } 20 \mathrm{ft} \text { ). Sand lance switch between } \\
\text { burying in the substrate and swimming in well-formed schools. Sand lance } \\
\text { usually occur in fine gravel and sandy substrates that are well-washed, } \\
\text { drained, and unpacked. These sediments usually are coarse sands with little or } \\
\text { no mud and silt. Sand lance activity patterns involve distinct crepuscular } \\
\text { (morning and evening) vertical movements between benthic substrates to } \\
\text { pelagic waters where sand lance feed on zooplankton. This behavior of } \\
\text { schooling in the day for feeding and burrowing at night reduces predation over } \\
\text { the daily cycle. }\end{array}$ & $\begin{array}{l}\text { Robards and Piatt } \\
\text { (1999) }\end{array}$ \\
\hline Prey & $\begin{array}{l}\text { Johnson et al. studied the distribution and habitat use of Pacific sand lance in } \\
\text { several shallow-water habitats in southeastern Alaska. Sand lances generally } \\
\text { occur in waters shallower than } \mathbf{4 0} \boldsymbol{m} \text { (131 ft). Johnson et al. caught sand } \\
\text { lance in all sampled habitat types, including understory kelp, bedrock } \\
\text { outcrops, sand, and eelgrass. The authors found that sand lances used several } \\
\text { shallow-water habitats for at least } 4 \text { months in spring and summer and that } \\
\text { habitat was not limited to sandy substrates for burrowing. Sand lance occurred } \\
\text { in bedrock, eelgrass, and kelp, probably for feeding. }\end{array}$ & $\begin{array}{l}\text { Johnson et al. } \\
\text { (2008) }\end{array}$ \\
\hline Prey & $\begin{array}{l}\text { Haynes and Robinson studied young-of-the-year sand lance reuse of sediment } \\
\text { patches in intertidal and shallow subtidal regions of Barkley Sound, British } \\
\text { Columbia, Canada. The study found that, within each summer, batch-marked } \\
\text { sand lance reused the same sediment patch as long as } 8 \text { weeks after } \\
\text { marking. Re-sampling over a 4-month period in } 2002 \text { showed that sand lance } \\
\text { consistently occupied patches within a season. The results generally support } \\
\text { the hypothesis that during their first growing season, sand lance show a } \\
\text { certain fidelity to the site at which they settle. }\end{array}$ & $\begin{array}{l}\text { Haynes and } \\
\text { Robinson (2011) }\end{array}$ \\
\hline
\end{tabular}

Sections 3.1 through 3.7 summarize information gathered during the literature review about various aspects of marbled murrelet biology. Section 3.8 assembles that information in a technical summary that addresses the specific concerns raised about the interaction between wave parks and the marbled murrelet. Finally, Section 3.9 distills the technical information into a more general form that would be suitable for a broader audience.

\subsection{Marbled Murrelet General Biology}

The marbled murrelet is a small seabird that belongs to the Family Alcidae. It is one of three species within the genus Brachyramphus. Marbled murrelets breed only from California to Alaska in western North America (Piatt et al. 2006). Marbled murrelets attain body lengths of about 23 to $25 \mathrm{~cm}$ (9 to 10 in.), have wing lengths of about 122 to $149 \mathrm{~mm}$ (5 to 6 in.), and adult weights that range from 188 to 269 
g (7 to 9.5 oz). During summer months, marbled murrelets feed mainly on small schooling fish (Section 3.6). During spring and winter, marbled murrelets prey primarily on planktonic invertebrates, including euphausiids and mysids. Marbled murrelets are pursuit-diving feeders that use their wings for locomotion underwater. However, marbled murrelets have retained the ability to fly. Murrelet wing area is reduced to decrease underwater drag, its breast muscles are well-developed for underwater locomotion, and the body mass-to-wing area ratio (wing-loading) is high. The distinctive feature of marbled murrelet biology is that the birds nest in old-growth forests that often are located inland, several miles from the coast. Nesting sites are often remote and so poorly accessible to scientists that modern understanding of nesting and breeding dates to only 1974 when a nest was discovered in central California (Piatt et al. 2006). Typically there is one egg per clutch. Murrelets incubate eggs about 30 days, and chicks fledge within about 27 to 40 days after hatching. Nesting season varies with latitude; nesting starts earlier in southern parts of the species' range than in northern parts. In the Oregon area, nesting begins around the end of April and ends in late September (Piatt et al. 2006). Although marbled murrelets show considerable site fidelity by returning to the same general forest areas to nest, individual nest sites might not be used in consecutive years. Site fidelity means that if the forest stand used by murrelets is cut, those birds may not breed again (USFWS 2012).

\subsection{Status and Threats to Marbled Murrelets}

The USFWS listed the Washington, Oregon, and California distinct population segments (DPSs) of the marbled murrelet as federally threatened on October 1, 1992 (57 FR 45328), and designated areas in Washington, Oregon, and California as critical habitat for the species on May 24, 1996 (61 FR 26256). The USFWS (1997) developed a Marbled Murrelet Recovery Plan that identified six conservation zones (Figure 3.1) throughout the listed range of the species: Puget Sound (Conservation Zone 1), Western Washington Coast Range (Conservation Zone 2), Oregon Coast Range (Conservation Zone 3), Siskiyou Coast Range (Conservation Zone 4), Mendocino (Conservation Zone 5), and Santa Cruz Mountains (Conservation Zone 6). The USFWS conducted 5-year reviews of the species' status in 2004 and 2009, each time confirming its Threatened status. The USFWS revised marbled murrelet critical habitat on October 5, 2011 for areas in Oregon and northern California. In Oregon, critical habitat includes forested areas that approach the coast in Tillamook, Lincoln (S of Newport), Lane, and Douglas Counties (76 FR 61599). Designated critical habitat is located about 6 miles east of the proposed Reedsport wave park in the Umpqua River Basin (FERC 2010).

The USFWS established a Recovery Implementation Team (RIT) in October 2011 to evaluate the causes of the murrelet population decline in Washington, Oregon, and California (USFWS 2012). The RIT also was tasked with determining the relative importance of these causes and developing short-term actions that could be implemented to reduce the population's decline. The USFWS also engaged regional stakeholders in these activities. The RIT identified forest nesting habitat loss, predation on murrelet eggs and chicks, marine prey changes (abundance, distribution, and quality), post-fledging mortality, and, finally, cumulative and interactive effects, as the five main threats to murrelets.

\subsection{Marbled Murrelet Marine Abundance and Habitat Use}

Falxa et al. (2011) presented the results from the 2009 and 2010 marbled murrelet at-sea monitoring survey that included density and population estimates for each conservation zone. The 2010 breeding season density estimates for Zones 1 through 4 ranged from to 0.78 to $4.53 \mathrm{birds} / \mathrm{km}^{2}$; densities were 
higher in Zones 3 and 4 (4.53 and 3.16 birds $/ \mathrm{km}^{2}$, respectively). Falxa et al. (2011) listed the total murrelet population estimate in Zones 1 through 5 for 2010 as about 16,700 birds, with the 95\% confidence limits ranging from about 13,100 to 20,300 birds. Conservation Zone 3 (Columbia River to Coos Bay, Oregon; the Reedsport wave park would be in this zone) had the largest estimated marbled murrelet population at 7223 birds (lower and upper 95\% confidence limits $=4605$ and 9520 birds). Falxa et al. (2011) estimated that the mean rate of annual decline from 2001 through 2010 was 3.7\% (95\% confidence interval $=-2.7$ to $-4.8 \%$ ), which represented a total population decline of about $29 \%$.

It is clear from the literature that marbled murrelets are seabirds that remain relatively close to shore and do not usually travel long distances from nesting areas, although most of the available studies concerned birds in Alaska or off Vancouver Island, British Columbia. Off British Columbia, almost all marbled murrelets occurred within $2 \mathrm{~km}(1.2 \mathrm{mi})$ of shore; 75\% of the birds were within $0.6 \mathrm{~km}(0.4 \mathrm{mi})$ of shore (Burger et al. 2008). Burger et al. (2008) reported marbled murrelet densities at 45 birds $/ \mathrm{km}^{2}$ (17 birds $/ \mathrm{mi}^{2}$ ) inshore and about $11 \mathrm{birds} / \mathrm{km}^{2}$ (4 birds $/ \mathrm{mi}^{2}$ ) offshore. Murrelets usually were where water depths were less than $20 \mathrm{~m}$ (66 ft). Juvenile murrelet densities were greater near sandy substrates, estuaries, and where water temperatures were cool (Yen et al. 2004). Hébert and Golightly (2008) found that murrelets typically were within about $1.4 \mathrm{~km}(0.9 \mathrm{mi}$.) of shore in northern California. Murrelets traveled less than $99 \mathrm{~km}$ (62 mi.) from the mouth of the creek whose watershed was the main nesting area. Off northern California and southern Oregon, Miller et al. (2002) found that marbled murrelet abundance was greatest in offshore areas located near inland areas that had large, unfragmented blocks of old-growth forests. Old-growth forests next to medium-size second-growth forests were particularly important. 


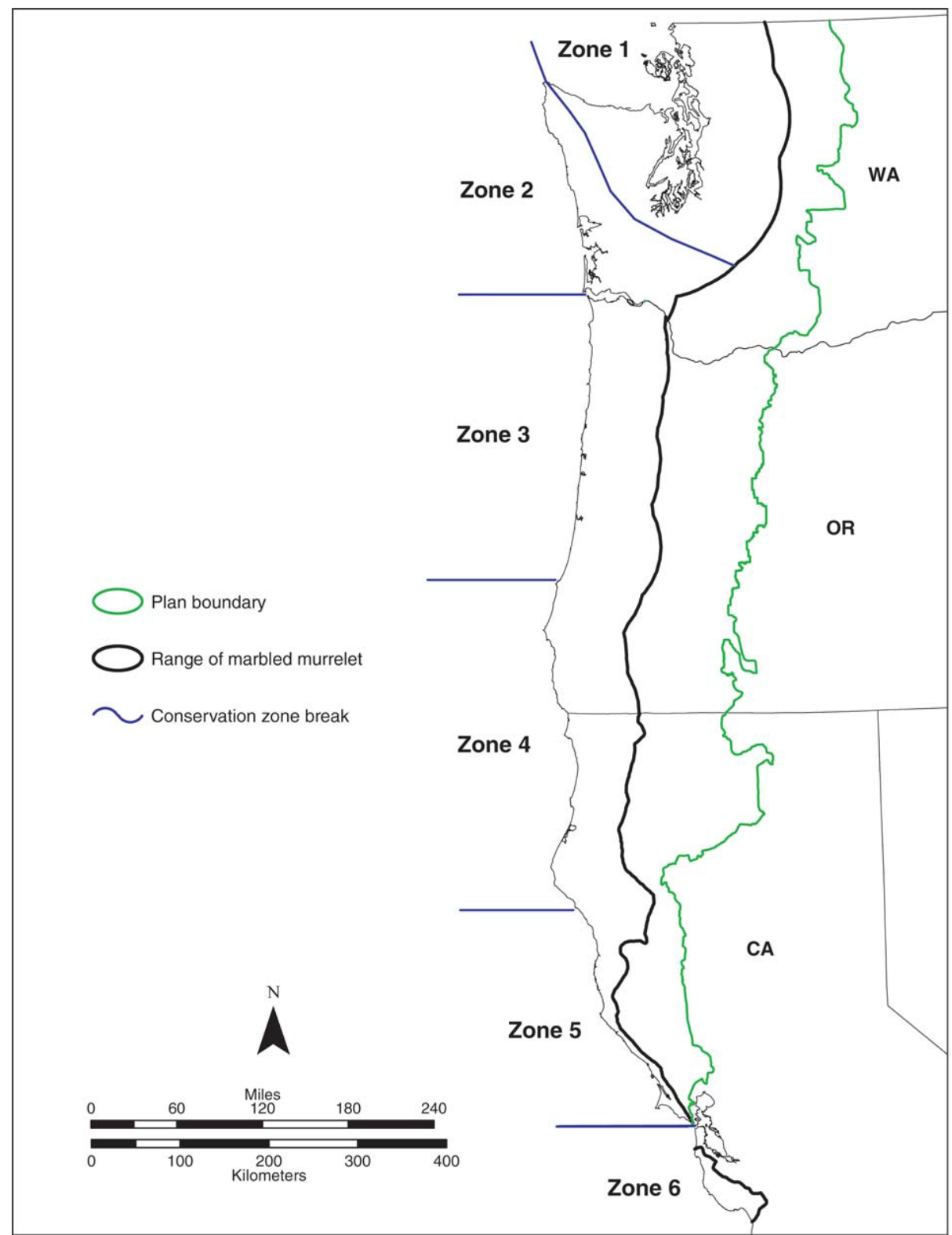

Figure 3.1. The six geographic areas identified as marbled murrelet conservation zones in the recovery plan for the species (USFWS 1997).

\subsection{Marbled Murrelet Flight}

Marbled murrelets flight capabilities are somewhat constrained by the dual use of the wings to provide for locomotion in air and underwater. To maneuver effectively underwater, murrelet wings are relatively short and narrow, which means that the body mass-to-wing area ratio (i.e., wing-loading) is high (Piatt et al. 2006). To compensate for the high wing loading, murrelets have developed a rapid, wing-flapping flight, although they are not particularly maneuverable flyers. Cooper et al. (2001) used radar to study marbled murrelet flight movements and speeds in Washington and found that birds averaged about $91 \mathrm{~km} / \mathrm{h}(56.5 \mathrm{mph})$ when flying inland but reached $102 \mathrm{~km} / \mathrm{h}(63.4)$ when flying toward the sea. The speeds recorded during the study ranged from 53 to $156 \mathrm{~km} / \mathrm{h}$ (33 to $97 \mathrm{mph}$ ). Elliott et al. 
(2004) found that the mean marbled murrelet speed was about $22.6 \mathrm{~m} / \mathrm{s}(81.4 \mathrm{~km} / \mathrm{h})$ was significantly faster than the maximum-range speeds (Vmr) predicted by four aerodynamic models. Elliott et al. (2004) also found no significant difference in flight speeds measured during low (darkness) or high (daylight) predation periods or between chick-rearing and nonbreeding periods. The authors determined that the current aerodynamic models are insufficient for this exceptionally fast-flying bird.

Stumpf et al. (2011) reported that marbled murrelets flying over land were at least $62 \mathrm{~m}(203 \mathrm{ft})$ above the ground and averaged flying at about $246 \mathrm{~m} \mathrm{(807} \mathrm{ft)} \mathrm{above} \mathrm{ground.} \mathrm{The} \mathrm{literature} \mathrm{review} \mathrm{did} \mathrm{not}$ encounter any measurements of marbled murrelet flight heights over water, but as pursuit-diving birds, it is very likely that they fly over water at low altitudes. Nelson et al. (2009) reported that there were no known records of collisions between marbled murrelets and wind turbines at the time the report was written, but they included the caveat that wind turbines had not yet been built in the marbled murrelet range. The literature review did not identify any studies that documented collisions between marbled murrelets and wind turbines.

\subsection{Marbled Murrelet Diving and Foraging Patterns and Swim Speeds}

Jodice and Collopy (1999) measured marbled murrelet dives in coastal waters along the Oregon coast that ranged from 3 to $36 \mathrm{~m}$ (10 to $118 \mathrm{ft}$ ). Marbled murrelet mean dive bout (three or more consecutive dive cycles) duration was about 28 to 33 min. During dive bouts, marbled murrelet spent about 50 to $62 \%$ of the time underwater. The time between successive dive bouts was about 50 to 76 min. Most dive bouts occurred in water $<10 \mathrm{~m}$ deep (Jodice and Collopy 1999). There was no significant relationship between dive time and water depth in this study, which was likely related to murrelets feeding in the water column rather than on benthic substrates. Peery et al. (2009) reported that in the Año Nuevo region of California, breeding marbled murrelets dove more while nesting than before or after nesting. They also dove more than nonbreeding birds. Murrelet mean dive time for an individual dive was about $23.5 \mathrm{~s}$, and mean surface interval after a dive was about $11 \mathrm{~s}$. Nesting murrelets monitored during the study foraged more intensively in the early daylight (0600-0900 hours) than did other individuals.

The literature search did not identify studies of underwater swimming speed of marbled murrelets but did find studies for other alcid species. Watanuki et al. (2006) studied four alcid species and found that while descending through the water column, the birds used wing up and down strokes to maintain average speeds of about 1.1 to $1.6 \mathrm{~m} / \mathrm{s}$ ( 2.5 to $3.6 \mathrm{mph}$ ). There was no indication that birds necessarily slowed during the descent but that they often increased speed by 0.2 to $0.5 \mathrm{~m} / \mathrm{s}(0.4$ to $1.1 \mathrm{mph})$. Watanuki et al. (2006) also found that while ascending to the surface, birds averaged swim speeds that ranged from about 1.6 to $1.8 \mathrm{~m} / \mathrm{s}$ (3.6 to $4.0 \mathrm{mph}$ ). Birds did not use their wings while ascending at depths shallower than 30 $\mathrm{m}$ and often increased speed by 0.2 to $0.5 \mathrm{~m} / \mathrm{s}$ (0.4 to $1.1 \mathrm{mph})$. Watanuki et al. (2003) found that Brünnich's guillemots (Uria lomvia) averaged about 1.2 to $1.8 \mathrm{~m} / \mathrm{s}$ during descent dives. The same study found that birds typically increased speed while ascending, probably because of increasing buoyancy during the ascent, to speeds of about $2.3 \mathrm{~m} / \mathrm{s}(5.1 \mathrm{mph})$. Watanabe et al. (2011) compiled data from several studies that showed a somewhat increasing relationship between swim speed and body mass for diving birds. However, within speeds of about 1 to $2 \mathrm{~m} / \mathrm{s}$ there did not appear to be a relationship between speed and size. Therefore, although the species studied by Watanuki et al. $(2003,2006)$ are about three times the size (body mass) of marbled murrelets, the studies may provide at least an upper limit to expected speeds of marbled murrelets during diving. 


\subsection{Marbled Murrelet Diet}

Piatt et al. (2006) summarized several studies on marbled murrelet diets that showed that small schooling fish were the predominant prey during summer months, whereas larger planktonic crustaceans were predominant in spring and winter months. Primary fish prey were Pacific sand lance (Ammodytes hexapterus), northern anchovies (Engraulis mordax), Pacific herring (Clupea harengus), and capelin (Mallotus villosus); primary invertebrate prey were euphausiids and mysids. Murrelets usually fed their chicks single large subadult or adult fish (larger sand lance, immature herring, and occasionally salmon smolt) that have higher energy value than larval or juvenile fish.

Several studies used stable isotopes to examine changes in marbled murrelet diets in the long term (decades) or short term (years/seasons). Analyses suggested that marbled murrelet diets in some areas switched from fish to invertebrates as fishing pressure caused fish populations to decline. Becker and Beissinger (2006) found that $\delta 15-\mathrm{N}$ and $\delta 13-\mathrm{C}$ levels in pre-breeding birds in central California declined over the past century, which suggested that krill increased and fish have decreased in importance in marbled murrelet diets over that period. The authors linked the change to the collapse of the Pacific sardine (Sardinops sagax) fishery in the late 1940s and later declines of similar fisheries. Post-breeding bird isotope levels have not changed significantly over time, implying that those birds' diets have not changed importantly.

Pacific sand lance is one of the main prey for marbled murrelets. Pacific sand lance are narrow, elongate fish that grow to a length of about $26 \mathrm{~cm}$ (10.2 in.). Sand lance are abundant in shallow nearshore areas usually in waters less than $50 \mathrm{~m}$ (164 ft) deep (Robards and Piatt 1999). Sand lance bury in clean, sandy sediments by night and swim is schools in the water column during the day. The switch from one habitat to the other generally occurs in the morning and evening. Although sandy substrates are a primary habitat, sand lance occur in other shallow-water habitats including understory kelp, eelgrass (Zostera marina), and bedrock outcrops (Johnson et al. 2008). Young-of-the-year sand lance show a certain degree of fidelity to the sand patch on which they settled, often reoccupying the patch for as long as 8 weeks (Haynes and Robinson 2011).

\subsection{Marbled Murrelet Predators}

Nest predation is an important factor in marbled murrelet life history. Predation caused about $78 \%$ of nest failures in case where nest outcomes were known (Nelson et al. 2006). The primary nest predators are Steller's jay (Cyanocitta stelleri) and the common raven (Corvus corax), both in the family Corvidae (Nelson et al. 2006; Peery and Henry 2010). Malt and Lank (2009) showed that increasing "hard” forest edge, such as result from clear-cutting forests, increases nest predation risk compared to areas where forests are regenerating or intact.

Predation on adult birds is not well documented. Other than lists of possible predators in general review articles, the literature search did not identify any studies specifically addressing predation of birds at sea. Piatt et al. (2006) listed bald eagles (Haliaeetus leucocephalus), peregrine falcons (Falco peregrinus), northern goshawks (Accipiter gentilis), sharp-shinned hawks (A. striatus), and common ravens as known or suspected murrelet predators. Haynes et al. (2010) speculated that great horned owls (Bubo virginianus) might feed on murrelets. No data on predation rates were available. 


\subsection{Putting It All Together}

Assessing the potential effects of the proposed Reedsport wave park on the marbled murrelet involves two basic questions-first, is it likely that marbled murrelets would occur in the project area? Second, would any of the project's activities exacerbate the primary threats to the species? The offshore wave park facilities would not affect two of these threats, nesting habitat loss and predation on eggs, but could interact with two others, post-fledging mortality and marine prey changes.

To address the threat of post-fledgling mortality, the likelihood that murrelets would encounter the proposed wave park needs to be evaluated. If murrelets do encounter the wave parks, then threats associated with those encounters need to be evaluated. The wave park proposed for the Oregon coast would be located about $2.5 \mathrm{nmi}$ offshore in waters that are about 204 to $225 \mathrm{ft}$ deep (FERC 2012). Some of the designated critical habitat for marbled murrelets is located is located in the Umpqua River Basin, which is about $6 \mathrm{mi}$ east of the proposed project area (FERC 2010). Murrelets nesting in the basin would likely forage in the Reedsport project area. The reviewed literature suggests that most marbled murrelets use nearshore water areas that are generally within $1.2 \mathrm{mi}$ of the shoreline, but some nonbreeding birds may fly farther offshore (FERC 2010). Although the Oregon coast is part of the conservation zone that has the largest number of birds, murrelet densities in that zone averaged about $4.53 \mathrm{birds} / \mathrm{km}^{2}$ during the 2010 survey (Falxa et al. 2011). Considering the bird density in the general area and the size of the proposed wave park ( 30 ac or $0.121 \mathrm{~km}^{2}$ ), the likelihood of an individual marbled murrelet encountering the wave park seems very low.

Although the chance of a murrelet encountering a park is low, the likelihood that such an encounter could contribute to increased mortality should be considered. The most likely factors that would cause mortality to a murrelet encountering a wave park would be collision with above-water or subsurface structures. As pursuit-diving foragers, murrelets are fast fliers that probably fly relatively close to the water surface much of the time. However, they are not particularly maneuverable while in flight. The above-water structure of the wave buoy proposed for use at Reedsport is about $29.5 \mathrm{ft}$ tall and has a maximum diameter of $36 \mathrm{ft}$, although most of the structure is much smaller in diameter. Thus, the structure presents a small target for flying birds. Also, buoys would be placed about $330 \mathrm{ft}$ apart, which would lower the likelihood that a bird would encounter an above-surface structure. However, there could be a greater risk for collision with the wave buoys at night. Murrelets may fly farther from shore at night, although there is very little information about where, how fast, and how close to the water they fly. The above-water structures would be more difficult for a murrelet to detect at night than during the day. The wave buoy array must be lit, but the lighting is to aid in navigation and is specifically designed to minimize attracting birds to the buoy area. The counterpoint to this strategy is that the buoys would be harder for birds flying through the park to detect and avoid above-water structures.

Diving murrelets could collide with the subsurface components of a wave buoy during the descending and ascending phases of the dive. Although specific information about dive speeds for marbled murrelets is not available, information about other species suggests that marbled murrelet speeds underwater would be less than about $2 \mathrm{~m} / \mathrm{s}(4.5 \mathrm{mph})$. Because Marbled murrelets are pursuit divers and continually swim during the dive descent, they may not necessarily slow down as the descent proceeds. Swim speeds are likely greater during that final ascent phase than at other times during the dive. Therefore, the risk of injury from collision with the wave park structures does not seem likely to decrease during the descent and probably increases during the latter parts of the ascent. The largest subsurface structural element comprises the main body of the buoy, which has a relatively small diameter, the underwater floats, and 
the catenary lines. The underwater floats and most of the catenary lines would be placed at depths of about 30 to $50 \mathrm{ft}$ (FERC 2010). Although murrelets can dive to a depth of more than $100 \mathrm{ft}$, most dives are to depths shallower than $33 \mathrm{ft}$. Therefore, most of the underwater structural elements that pose a collision risk to murrelets are deeper than the usual depths to which murrelets dive.

The other main threat to marbled murrelets to which a wave park could contribute is changing the marine prey base of the birds. The literature showed that marbled murrelets feed on a variety of small fish and larger planktonic invertebrates, and that some species are particularly important, at least at certain times of the year. The possible interaction between a wave park and prey fish species could include attraction as artificial reefs or fish-attraction devices (FADs), modification of benthic habitats, and increased numbers of predators (birds and marine mammals). The Pacific sand lance possibly is the most important prey species in the marbled murrelet diet and can be used as an example of how a wave park might affect marbled murrelet prey. The Pacific sand lance is a relatively small fish that swims in schools during the day but burrows into sediment at night. Sand lance generally occur in nearshore waters, usually at depths shallower than about 131 to $164 \mathrm{ft}$ (40 to $50 \mathrm{~m}$ ). Sand lance would not be expected to be attracted to wave buoys as artificial reefs or FADs because of the small footprint within the wave park that the structural elements would occupy (about 2\%; FERC 2010). The placement of the wave buoy anchors on the sediment could change sediment transport patterns and subsequently change sediment texture in the area that would make the sediment less (or more) likely to be used by sand lance. However, the small size of the anchors argues for little sediment transport change, except on a very small scale. When coupled with the typical occurrence of sand lance in waters much shallower than depths at the wave park, it seems very unlikely that the wave park would have any effect on the Pacific sand lance. Therefore, it is unlikely that a wave park would change murrelet feeding dynamics.

In summary, it is possible that marbled murrelets could encounter the wave park proposed for Reedsport, Oregon, but the studies referenced above suggest that most birds would pass by the park over shallower waters that are closer to shore and that the marbled murrelet prey dynamics would not be significantly affected by the park. Although the interaction between the proposed wave park and marbled murrelets cannot be excluded, the description of the wave park and the literature on murrelet biology suggest that the likelihood of an adverse interaction between the park and murrelets is low.

\subsection{The Reedsport, Oregon Coastal Wave Park Should Not Adversely Affect Marbled Murrelets}

The marbled murrelet (Brachyramphus marmoratus; Figure 3.2) is a small seabird that is distinctive because it nests in old-growth forests that often are located inland, several miles from the coast (Piatt et al. 2006). Marbled murrelets are pursuit-diving feeders that use their wings for locomotion underwater. Because of this use, murrelet wing area is reduced to decrease underwater drag, and the body mass-towing area ratio (wing-loading) is high. Murrelets are fast, but not highly maneuverable, fliers (Burger and Chatwin 2002; Elliott et al. 2004). Murrelets feed mainly on small schooling fish, such as Pacific sand lance (Ammodytes hexapterus), and larger planktonic crustaceans, such as mysids and euphausiids (krill) (Piatt et al. 2006). 
The USFWS listed the Washington, Oregon, and California distinct population segments (DPSs) ${ }^{1}$ of the marbled murrelet as federally threatened in 1992 (57 FR 45328) and designated areas in Washington, Oregon, and California as critical habitat for the species in 1996 (61 FR 26256). The USFWS (1997) developed a Marbled Murrelet Recovery Plan that identified six conservation zones, one of which includes forested areas that approach the Oregon coast in Tillamook, Lincoln (south of Newport), Lane, and Douglas counties (76 FR 61599). Designated critical habitat is located about 6 mi east of the proposed Reedsport wave park in the Umpqua River Basin (FERC 2010).

The USFWS established a Recovery Implementation Team (RIT) in 2011 to evaluate the causes of the murrelet population decline in Washington, Oregon, and California (USFWS 2012). The RIT identified forest nesting habitat loss, predation on murrelet eggs and chicks, marine prey changes (abundance, distribution, and quality), post-fledging mortality, and, finally, cumulative and interactive effects as the main threats to murrelets. The species' status and its use of nearshore habitats during foraging and migrations raised concern that placing a wave park, such as that proposed for Reedsport, Oregon, in coastal areas could interfere with marbled murrelet feeding and migration.

The review articles identified several potential factors by which wave farms could affect seabirdsthese factors appeared consistently. Probably the most important direct effect of MHK wave parks on seabirds is potential injury or mortality resulting from collisions with above-water structures. Collisions with underwater structural elements constitute another risk for some diving bird species. The primary indirect effect of wave parks on seabirds is related to potential changes in food web dynamics.

\footnotetext{
1 A DPS is the smallest division of a taxonomic species that is permitted to be protected under the ESA. A DPS must be distinct from and significant to the rest of the species to which it belongs. A DPS must be able to be assigned a conservation status according to the ESA.s standards for listing.
} 


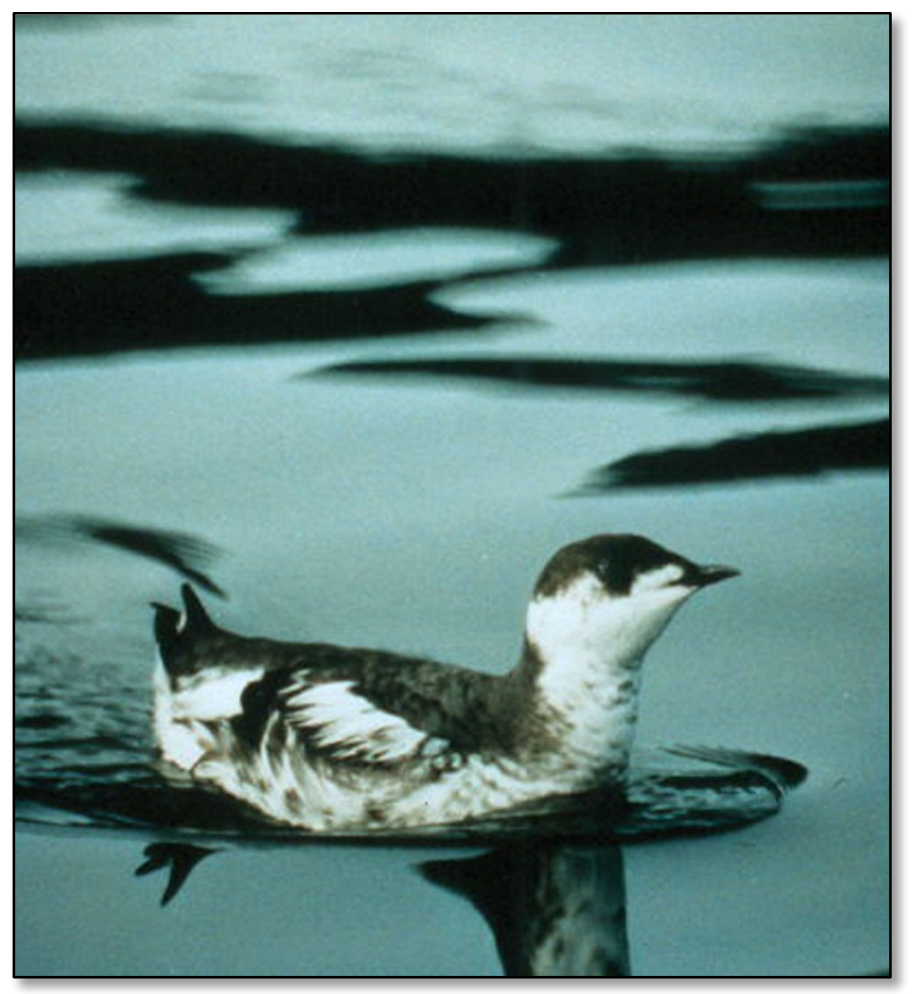

Figure 3.2. The marbled murrelet (Brachyramphus marmoratus). This image is the work of a USFWS employee, taken or made during the course of the employee's official duties. As a work of the U.S. federal government, the image is in the public domain.

The wave park proposed for the Oregon coast would be located about $2.5 \mathrm{nmi}$ off Reedsport (FERC 2010). The park eventually would contain 10 wave buoys spaced about $330 \mathrm{ft}$ apart encompassing an area of about 30 ac. The width of the park presented to flying marbled murrelets probably would be no more than $1000 \mathrm{ft}$. Water depths at the park range from 165 to $225 \mathrm{ft}$, although most of the project structures probably would be deeper than $204 \mathrm{ft}$ (FERC 2012). Each wave buoy would have a maximum diameter of $36 \mathrm{ft}$, extend $29.5 \mathrm{ft}$ above water, and have a maximum draft of $115 \mathrm{ft}$. Three 160 -ft catenary lines would moor each power buoy to 3 of 16 anchors in the array via subsurface floats placed at a water depth of about 30 to $50 \mathrm{ft}$; 105-ft tendon lines would run from the float to the anchor on the seabed (Figure 2.2). Power generated by the buoy array would be carried to shore via an armored subsea transmission cable, buried in the seabed to a depth of 3 to $6 \mathrm{ft}$ (FERC 2012). The cable would extend from the underwater substation pod to the outlet of an existing wastewater discharge pipeline about $0.5 \mathrm{mi}$ from shore. The subsea cable would enter the discharge pipeline and extend through the pipeline passing under the nearshore area, beach, and dunes. Probably the most important direct effects of an MHK wave park on marbled murrelets are the collisions with above-water and underwater structures and habitat changes that could affect marbled murrelet prey dynamics. These effects align with two of the principle threats to the species identified by the RIT (USFWS 2012).

To evaluate these risks, a first step is to describe the typical at-sea habitat used by foraging and migrating marbled murrelets. Several studies showed the marbled murrelets usually remain relatively close to shore and do not often travel long distances from nesting areas (Burger et al. 2008, Hébert and Golightly 2008). Also, marbled murrelet abundance is typically greatest in offshore areas that are located 
near inland areas that have large, unfragmented blocks of old-growth forests (Miller et al. 2002). Although the Oregon coast is part of the conservation zone that has the largest number of birds, murrelet densities in that zone averaged about 4.53 birds $/ \mathrm{km}^{2}$ (about 2 birds/100 ac) during the 2010 survey (Falxa et al. 2011). Considering the bird density in the general area and the size of the proposed wave park (30 ac or $0.121 \mathrm{~km}^{2}$, most foraging and migrating marbled murrelets probably would not encounter the wave park directly and would not be exposed to the risks posed by it. Some foraging and migrating marbled murrelets may encounter the wave park directly and be exposed to the risks of doing so.

The placement of above-water and underwater structures in a nearshore area where none existed previously presents a collision risk to flying or diving marbled murrelets that encounter the wave park. The risk is heightened because marbled murrelets are fast fliers with relatively low maneuverability skills (Burger and Chatwin 2002, Elliott et al. 2004). Murrelets probably fly at over the water at low altitudes, although this is not well documented. The risk of above-water collisions would be ameliorated by the relatively low size of each wave buoy ( $29.5 \mathrm{ft}$ tall, about $8 \mathrm{ft}$ in diameter except at the water surface) and the 330-ft spacing between the buoys. The buoys would not have above-water stays or guy wires, which reduces the collision risk to the birds (FERC 2010). The risk of collision with above-water structures might be greater at night because murrelets tend to fly farther offshore then (Haynes et al. 2010) and the structures would be harder to see. Very little information is available about where, how fast, and how close to the water they fly at night. The wave buoy array must be lit at night, but the lighting is to aid in navigation and is specifically designed to minimize attracting birds to the buoy area. The counterpoint to this strategy is that the buoys would be harder for birds flying through the park to detect and avoid abovewater structures.

The underwater structures with which a diving murrelet might collide include the catenary lines, subsea float, and the anchors. There is a risk that marbled murrelets could collide with underwater structures during the descending and ascending dive phases. The risk likely would not diminish with increasing depth of the dive because the birds swim throughout the dive, often increasing swim speed. The collision risk may be somewhat greater during the ascent phase because the birds may attain faster speeds before reaching the surface. Although murrelets can dive to a depth of $118 \mathrm{ft}$, most dives are to waters less than $33 \mathrm{ft}$ deep. The largest wave buoy underwater structures are the subsea float and the anchor. The subsea float would be placed at a depth of about 30 to $50 \mathrm{ft}$, and the anchors situated at about $200 \mathrm{ft}$ or deeper. The subsea floats would be at or deeper than the depth of most murrelet dives. The anchors would be deeper than the deepest murrelet dive depths. The catenary lines would be within murrelet dive range but are of relatively small diameter, which reduces the risk of collision for a diving bird.

A wave park would introduce new habitat structure into nearshore waters. The underwater structures in the wave park could act as artificial reefs that would attract fish species not normally found in open nearshore waters. These fish most likely would be normally associated with rocky habitats (Thompson et al. 2008). The surface floats supporting the wave buoy could act as fish-attraction devices, which could provide shelter to small, schooling forage fish. These new habitats could affect marbled murrelet predator-prey dynamics. Thus, the low density of marbled murrelets in the immediate area near the proposed wave park and the small size and the placement of the wave buoy above-water and underwater structures contribute to an overall collision risk that is low but that cannot be completely discounted.

To evaluate this concern, the first step is to identify the primary marbled murrelet prey. Murrelets usually forage in waters that are shallower than $33 \mathrm{ft}$ deep, although they can dive as deep as $118 \mathrm{ft}$ 
(Jodice and Collopy 1999). Murrelets feed primarily on small schooling fish and larger planktonic crustaceans, but the most important prey is the Pacific sand lance (Ammodytes hexapterus), especially during breeding season (Jodice and Collopy 1999; Strong 2005; Piatt et al. 2006).

The next step is to evaluate the behavior of the prey and assess whether it is likely to interact with the wave buoy structures. The Pacific sand lance is a relatively small fish that swims in schools during the day but burrows into sediment at night. Sand lance generally occur in nearshore waters, usually at depths much shallower than about 131 to $164 \mathrm{ft}$. Therefore, sand lance probably would not encounter the main wave park structures often. Sand lance also would not be expected to be attracted to wave buoys as artificial reefs or FADs because of the small footprint within the wave park that the structural elements would occupy (about 2\%; FERC 2010). The placement of the wave buoy anchors on the sediment could change sediment transport patterns and subsequently change sediment texture in the area that would make the sediment less (or more) likely to be used by sand lance. However, the small size of the anchors argues for little sediment transport change, except on a very small scale. When coupled with the typical occurrence of sand lance in waters much shallower than depths at the wave park, it seems very unlikely that the wave park would have any effect on the Pacific sand lance. Therefore, it is unlikely that a wave park would change murrelet feeding dynamics.

Evidence gathered to date indicates that although the marbled murrelet may encounter the proposed wave park, the park should not adversely affect foraging or migrating marbled murrelets by increasing their risk of injury from collisions with above-water and underwater structures or by altering predatorprey dynamics. 


\subsection{Green Sturgeon Case Study}

The articles summarized in this section were derived from the original general literature search to determine the primary topics of concern regarding the potential effects of MHK devices on fish and a focused literature search concerning green sturgeon (Acipenser medirostris). The possible effects of marine renewable energy devices on fish as listed in key review articles (e.g., Boehlert et al. 2008, Nelson 2008, and Boehlert and Gill 2010) were examined to begin the search process (Table 3.1). Within these review articles, several potential factors by which wave parks could affect fish appeared consistently. Probably the most important direct effects of an MHK wave park on sturgeons are the collisions with underwater structures, effects of habitat alteration, and potential interruption of migration pathways by exposure to electromagnetic fields (EMFs). MHK wave parks may act as de facto protection areas because the parks probably would reduce fisher access to areas formerly available for fishing. The main habitat change is the addition of novel hard-substrate habitat to areas that formerly were primarily soft bottomed. This addition would eliminate some soft-bottom habitat and would create new "artificial reefs" that would be colonized by epifaunal organisms and rocky-bottom fish species. Wave parks would often be placed in areas where there is typically little hard substrate. The introduction of novel hard substrate into coastal waters eventually contributes to the development of new biological communities in the area. During the establishment of a wave park, some soft-bottom habitat would be replaced by hard structures.

Table 4.1. Reviewed literature that discusses the potential effects of marine wave parks on fish.

\begin{tabular}{l} 
Summary (Key Points in Boldface Italics) \\
\hline Wave energy devices placed and operated in nearshore habitat would change the \\
physical structure of the benthic and pelagic habitat available to fishes by adding \\
cables, floats, and mooring systems, thus adding physical structure where none \\
currently exists. Wave parks may serve as protected areas by limiting accessibility to \\
fishers. Wave energy devices would change wave-born physical energy into \\
mechanical energy, which would alter wave patterns and size as they approach the \\
shore. Wave energy devices are being placed in the migratory corridors of some \\
species. Boehlert et al. presented some specific concerns regarding the green \\
sturgeon. Green sturgeons migrate along the coast at depths of about 51 m (168 ft); \\
wave devices may be placed within this zone. Devices emit electromagnetic (EMF), \\
acoustic, and chemical fields at levels that interfere with fish navigation and \\
orientation systems. Devices may interrupt migration by deterring fish from entering \\
the area. The authors rated effects of EMFs and the wave device mooring system \\
and benthic habitat on green sturgeon as high; they listed decommissioning and \\
removal as moderate.
\end{tabular}




\begin{tabular}{|c|c|}
\hline Summary (Key Points in Boldface Italics) & Reference \\
\hline $\begin{array}{l}\text { Nelson stated that wave devices would alter nearshore habitats by introducing hard } \\
\text { substrate and vertical structure where none existed previously. Wave energy } \\
\text { conversion (WEC) facilities would act like artificial reefs and possibly as fish } \\
\text { aggregation devices. The added vertical relief and hard substrate of the "artificial } \\
\text { reef" would likely change local fish distributions and diversity by attracting natural } \\
\text { rocky reef-associated fishes to an area of formerly soft bottom. However, this } \\
\text { addition to soft-bottom habitat would represent a habitat loss for some species, } \\
\text { including the green sturgeon. WEC devices may generate acoustic and/or electrical } \\
\text { signals that may affect fish behavior. WEC devices may reduce onshore wave } \\
\text { energy within its the shadow, which could change beach characteristics and affect } \\
\text { beach-spawning species. Fishes respond to acoustic, mechanosensory, visual, } \\
\text { chemosensory, magnetic, and electrical stimuli. Therefore, immediately observable } \\
\text { effects on fish from WEC devices would likely be behavioral. Responses to these } \\
\text { cues could range from attraction to aversion. Because public access (including } \\
\text { fishing access) to WEC sites is likely to be curtailed for safety reasons, these sites } \\
\text { will probably function as de facto marine reserves. Green sturgeons migrate through } \\
\text { nearshore habitat where WEC arrays are likely to occur and may be affected by low } \\
\text { EMF levels. }\end{array}$ & Nelson (2008) \\
\hline $\begin{array}{l}\text { Boehlert and Gill listed the primary effects of wave devices on fish as creating an } \\
\text { artificial reef effect by the addition of novel settlement habitat for different } \\
\text { organisms to nearshore waters, removing energy from nearshore systems that could } \\
\text { lead to localized water movement and turbulence changes. These effects could lead } \\
\text { to habitat changes resulting from benthic sediment scouring. The authors mentioned } \\
\text { that there is the potential for chemical spills into nearshore waters, including } \\
\text { hydraulic fluid and chemicals from anti-fouling paints. Installing and operating the } \\
\text { devices would add noise to the environment. Electrical transmission cables emit low- } \\
\text { frequency electromagnetic fields, and the movement of water and organisms through } \\
\text { the EMFs would cause localized electric fields that would be likely to affect animals } \\
\text { that use EMFs for spatial location, large-scale movement, small-scale orientation, } \\
\text { feeding, or mate finding. The addition of physical structure to nearshore waters } \\
\text { would change pelagic habitats affecting fish community species composition. } \\
\text { Migrating fish could be affected by stressors, such as EMFs, chemical or acoustic } \\
\text { signals, or a combination of such stressors. }\end{array}$ & Boehlert and Gill (2010) \\
\hline $\begin{array}{l}\text { In its recovery outline for the green sturgeon southern DPS, NMFS identified } \\
\text { potential threats associated with ocean energy development. One main concern } \\
\text { identified is exposure to the EMF generated by project cables, turbine structures, } \\
\text { and junction boxes. Green sturgeon use electroreceptors for feeding and perhaps } \\
\text { migration, both of which may be affected by EMFs. Wave device arrays may act as } \\
\text { artificial reefs that would attract marine mammals, fish, and invertebrates. This } \\
\text { could change local marine community species composition, predator-prey } \\
\text { interactions (e.g., increased presence of sea lions), or the distribution and abundance } \\
\text { of marine species around ocean energy installation sites, and these sites are within } \\
\text { the migratory corridors of green sturgeon. }\end{array}$ & NMFS 2010 \\
\hline $\begin{array}{l}\text { FERC staff concluded that the proposed action is not likely to adversely affect the } \\
\text { green sturgeon or designated critical habitat for the species. FERC concluded that } \\
\text { the results of recent studies conducted on existing cables, which were similar to those } \\
\text { that would be used for the proposed Reedsport park, showed that that the effects of } \\
\text { EMFs on green sturgeon are expected to be minor (i.e., not deter the species from } \\
\text { using the area). }\end{array}$ & FERC (2010) \\
\hline
\end{tabular}

From these review articles, several general topics of potential environmental effects on fish were derived. Key points or effects identified by each reviewed paper (boldface italics), and their relevance to 
the evaluation of the effects of wave parks on green sturgeons, are captured in Table 4.2, which also includes a citation to the appropriate source as listed in Section 5 (References).

Table 4.2. Reviewed literature relevant to the potential effects of the placement of marine hydrokinetic devices on green sturgeon. The scientific names of species mentioned in the table are provided in the text.

\begin{tabular}{|c|c|c|}
\hline Green Sturgeon & Summary (Key Points in Boldface Italics) & Reference \\
\hline Population Status & $\begin{array}{l}\text { Adams et al. reviewed green sturgeon genetic analyses that showed } \\
\text { separate northern and southern populations. NMFS separated the species } \\
\text { into Northern and Southern Distinct Population Segments (DPSs). The } \\
\text { Northern DPS includes populations in the Rogue, Klamath-Trinity, and } \\
\text { Eel rivers, whereas the Southern DPS includes one population in the } \\
\text { Sacramento River. NMFS does not consider the Northern DPS to be in } \\
\text { danger of extinction or likely to become an endangered species in the } \\
\text { foreseeable future. The two main spawning populations in the Rogue and } \\
\text { Klamath-Trinity rivers occupy separate basins, reducing the potential for } \\
\text { loss of the DPS through catastrophic events. Green sturgeon in this DPS } \\
\text { do not face substantial entrainment loss. NMFS considers the Southern } \\
\text { DPS likely to become an endangered species in the foreseeable future. } \\
\text { Green sturgeon in this DPS are limited to one spawning area outside of } \\
\text { their natural habitat in the Sacramento River, making them vulnerable to } \\
\text { catastrophic extinction. Entrainment of individuals into water diversion } \\
\text { projects is an additional source of risk, and the large decline in numbers } \\
\text { of green sturgeon entrained since } 1986 \text { causes additional concern. }\end{array}$ & Adams et al. (2007) \\
\hline Threats & $\begin{array}{l}\text { The primary threat to the green sturgeon Southern DPS is reduction of } \\
\text { the spawning area to a limited section of the Sacramento River. } \\
\text { Insufficient freshwater flow rates in spawning areas, contaminants (e.g., } \\
\text { pesticides), bycatch of green sturgeon in fisheries, potential poaching } \\
\text { (e.g., for caviar), entrainment by water projects, influence of exotic } \\
\text { species, small population size, impassable barriers, and elevated water } \\
\text { temperatures likely pose a threat to green sturgeons. }\end{array}$ & NOAA (2011) \\
\hline
\end{tabular}




\begin{tabular}{|c|c|c|}
\hline Critical Habitat & $\begin{array}{l}\text { NMFS designated critical habitat for the green sturgeon southern DPS on } \\
\text { October 9, } 2009 \text {. Critical habitat within marine waters includes areas } \\
\text { within the } 60 \text { fathom [ } 360 \text { ft] isobath from Monterey Bay to the U.S.- } \\
\text { Canadian border. Many coastal bays and estuaries are designated as } \\
\text { critical habitat, including San Francisco Estuary and Humboldt Bay in } \\
\text { California; Coos, Winchester, Yaquina, and Nehalem bays in Oregon; } \\
\text { Willapa Bay and Grays Harbor in Washington; and the lower Columbia } \\
\text { River estuary from the mouth to river kilometer } 74 \text {. }\end{array}$ & 74 FR 52300 \\
\hline Electromagnetic Fields & $\begin{array}{l}\text { Fisher and Slater reviewed the literature on EMFs and marine animals. } \\
\text { The sources of EMFs from wave energy conversion projects are the } \\
\text { wave energy converter (WEC) device itself, the subsea pod, and the } \\
\text { subsea power transmission cables. EMFs consist of } \boldsymbol{E} \text { - and B-fields. } \\
\text { Magnetic B-fields can produce a weak electric field, referred to as an } \\
\text { induced electric (iE) field. E- and B-field strength depend on the type } \\
\text { and magnitude of current flowing through the cable and the construction } \\
\text { of the cable. E- and B-fields rapidly lose strength in seawater with } \\
\text { increasing distance from the source. Electrosensitive species detect iE- } \\
\text { fields passively (i.e., sense the iE-fields produced by the interaction } \\
\text { between ocean currents with the vertical component of the Earth's } \\
\text { magnetic field) or actively (i.e., sense the iE-field generated by their own } \\
\text { interaction in the water with the horizontal component of the Earth's B- } \\
\text { field). Data on the detection of B-fields by marine species is limited. } \\
\text { Sturgeons are weakly electrosensitive fish that use electroreceptor } \\
\text { senses, and others, to locate prey. No research has been conducted on } \\
\text { sturgeon species found in Oregon. Basov (1999; full reference not } \\
\text { available) found that sterlet sturgeon and Russian sturgeon behavior } \\
\text { varied in the presence of different E-field frequencies and intensities. At } \\
1.0 \text { to } 4.0 \text { hertz (Hz) at } 0.2 \text { to } 3.0 \mu \mathrm{V} / \mathrm{cm} \text {, fish searched for the source and } \\
\text { foraged actively; at } 50 \mathrm{~Hz} \text { at } 0.2 \text { to } 0.5 \mu \mathrm{V} / \mathrm{cm} \text {, fish searched for the } \\
\text { source; and } \boldsymbol{a t} \mathbf{5 0} \mathbf{H z} \text { at } \mathbf{0 . 6} \boldsymbol{\mu} \mathbf{V} / \mathrm{cm} \text { or greater, fish avoided the source. }\end{array}$ & $\begin{array}{l}\text { Fisher and Slater } \\
\text { (2010) }\end{array}$ \\
\hline Electromagnetic Fields & $\begin{array}{l}\text { The electromagnetic field created by electric current passing through a } \\
\text { cable has electric field (E field) and induced magnetic field (B field) } \\
\text { components. E fields can be contained within undamaged insulation } \\
\text { surrounding the cable, B fields are unavoidable and induce a secondary } \\
\text { electric field (iE field). Earth's natural magnetic flux densities range } \\
\text { from } 20 \text { to } 75 \boldsymbol{\mu T} \text {. The EMFs associated with new marine hydrokinetic } \\
\text { energy designs have not been quantified. Estimates of the B-field } \\
\text { strength produced by the current-carrying cable ranged from } 0 \text { to } 1.7 \text { and } \\
0.61 \mu \mathrm{T} \text { at distances of } 0 \text { and } 2.5 \mathrm{~m} \text { from the cable, respectively. Burying } \\
\text { a cable will not affect the B-field magnitude. EMFs generated by a multi- } \\
\text { unit array of hydrokinetic devices will differ from EMFs associated with } \\
\text { a single unit or from the single cable sources. There is concern that } \\
\text { EMFs from marine hydrokinetic facilities may change green sturgeon } \\
\text { migration routes. Estimated magnetic flux densities for cables are as } \\
\text { follows: at cable surfaces, values were very high-463-8000 } \boldsymbol{\mu T} \text {; } \mathbf{0 . 1} \mathbf{m} \\
\text { from the cable, values dropped to } 154 \text { to } \mathbf{8 9 0} \boldsymbol{\mu T} \text {, then to values within } \\
\text { earth background at } 1 \mathbf{m} \text { from cable. }\end{array}$ & Cada et al. (2011) \\
\hline
\end{tabular}




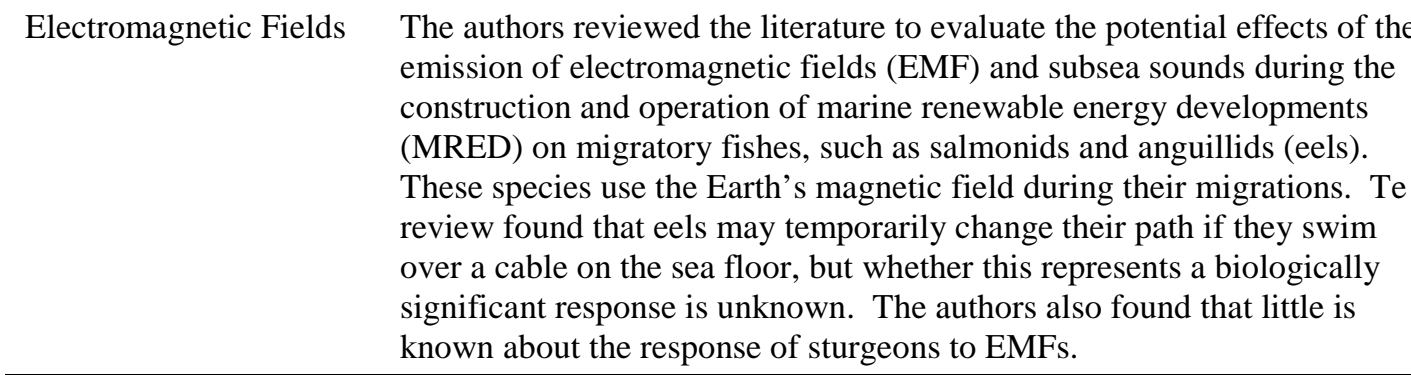

General Biology

At-Sea Habitat

Adams et al. reviewed green sturgeon status and biology. Green sturgeon are anadromous, spawning in freshwater about every 3 to 5 years and migrating to the ocean were they disperse widely although mostly to the north from natal rivers. The species is the most marine-oriented sturgeon. Green sturgeons spawn in only the Klamath, Sacramento, and Rogue rivers but range in nearshore waters from Mexico to the Bering Sea. Mature males range from 139 to199 cm (55 to 78 in.) in fork length and live to be 15 to 30 years old. Mature females range from 157 to 223 $\mathrm{cm}$ (62 to $88 \mathrm{in}$.) in fork length and live to be 17 to 40 years old. Juveniles migrate to the ocean after spending 1 to 3 years in freshwater. Green sturgeon begin returning to the Klamath River at about 15 to 17 years old. Green sturgeon feeding is not well known, but they most probably eat benthic invertebrates and small fish.

Huff et al. used data from 37 acoustically tagged green sturgeon tracked Spawning occurs from March to July but peaks in mid-April to mid-June. by a coastal array located along the Siletz Reef near Newport, Oregon (about $80 \mathrm{mi}$ north of the proposed Reedsport wave park site), to build a statistical model to characterize green sturgeon marine habitat. The authors found that green sturgeon usually spent more time in areas with high seafloor complexity, especially where a greater proportion of the substrate consists of boulders. They reported that green sturgeon in marine habitats occurred mainly at depths of 20 to $60 \mathrm{~m}(66$ to $197 \mathrm{ft})$ and where water temperatures were 9.5 to $16.0^{\circ} \mathrm{C}\left(49\right.$ to $\left.61^{\circ} \mathrm{F}\right)$. Green sturgeon spent more time along the north to south, $40 \mathrm{~m} \mathrm{(131} \mathrm{ft)} \mathrm{depth}$ contour than at other depths. The authors thought that many sturgeon in this study were likely migrating north, moving deeper, and may have been using complex seafloor habitat because it coincides with the distribution of benthic prey taxa or provides refuge from predators.

Erickson and Hightower tagged seven green sturgeon with pop-off archival tags in the Rogue River, Oregon. All fish left the river and entered the ocean within $32 \mathrm{~d}$ of tagging. All tagged sturgeons migrated north after entering the ocean; pop-off tag recovery locations ranged from the central Oregon coast to northwestern Vancouver Island, Canada. The authors estimated the distances that fish migrated through nearshore waters ranged from 221 to $968 \mathbf{~ k m}$ (137 to $601 \mathrm{mi}$ ). Erickson and Hightower identified potential concentration sites off the Oregon and Washington coasts near major coastal ports (e.g., Coos Bay to Newport, and Astoria, Oregon), major estuaries (e.g., Grays Harbor and Willapa Bay, Washington), and off northern Washington. Green sturgeon had a limited depth distribution over the continental shelf that was typically $<100 \boldsymbol{m}(<328 \mathrm{ft})$. The authors described occasional rapid vertical ascents to or near the surface, although green sturgeon typically occurred at depths of 40 to $70 \mathrm{~m}$ (131 to $230 \mathrm{ft}$ ). Green sturgeon were more active and occupied shallower depths at night than during the day.
Gill et al. (2012)

Adams et al. (2002)

Huff et al. (2011)

Huff et al. (2011)

Erickson and
Hightower (2007)




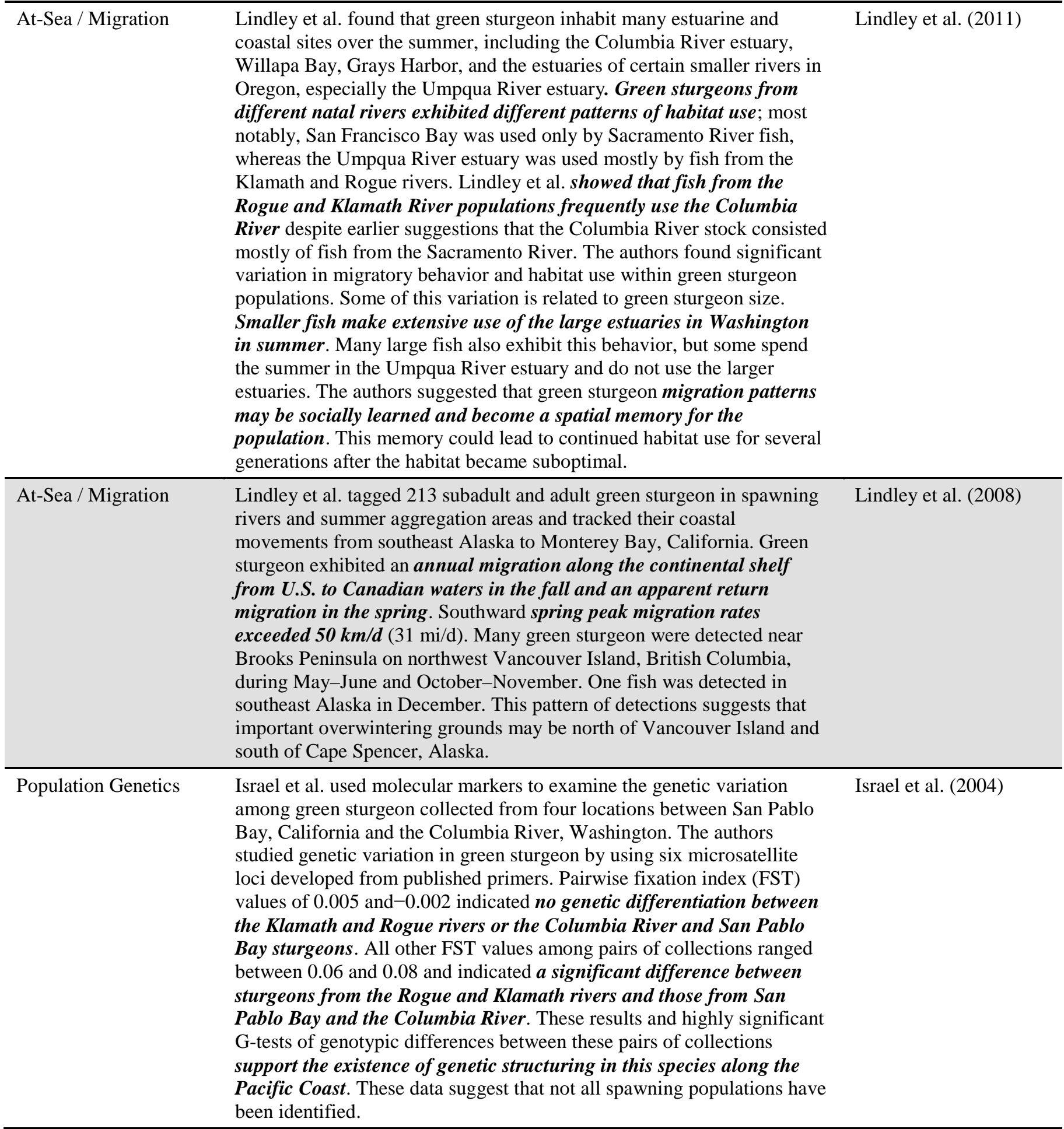




\begin{tabular}{|c|c|c|}
\hline Population Genetics & $\begin{array}{l}\text { Israel et al. used pairwise comparisons and genetic clustering analysis to } \\
\text { characterize the two green sturgeon distinct population segments (DPSs). } \\
\text { The observed pattern of green sturgeon DPS composition among five } \\
\text { estuaries in California, Oregon, and Washington was supported with } \\
\text { assignment testing approaches using the same genotypic data in } \\
\text { codominant polysomic and pseudodominant allele phenotype formats. } \\
\text { Most individuals found in Northern DPS estuaries originated from the } \\
\text { threatened Southern DPS, except in Winchester Bay and Grays Harbor. } \\
\text { The authors detected few Northern DPS green sturgeon in San Pablo } \\
\text { Bay, the principal Southern DPS estuary. The results support the idea } \\
\text { that green sturgeon preferentially disperse north once they enter their } \\
\text { coastal migration. }\end{array}$ & Israel et al. (2009) \\
\hline $\begin{array}{l}\text { Breeding Population } \\
\text { Size }\end{array}$ & $\begin{array}{l}\text { Israel and May estimated breeding population size indirectly from } \\
\text { collections of out-migrating juvenile green sturgeon. They evaluated a } \\
\text { polysomic dataset from green sturgeon to describe the relationship } \\
\text { among known progeny from experimental families. Israel and May } \\
\text { reconstructed green sturgeon pedigrees from juveniles of unknown } \\
\text { relationship by using the distributions of relatedness values for kin } \\
\text { classes. The authors determined that the estimated abundance of } \\
\text { breeding green sturgeon in the upper Sacramento River remained } \\
\text { roughly steady over a 5-year period, ranging from } 10 \text { to } 28 \text { individuals, } \\
\text { depending on the year and data analysis method. }\end{array}$ & Israel and May (2010) \\
\hline Swimming & $\begin{array}{l}\text { Kelly et al. found that non-directional movements were oriented with } \\
\text { the bottom; individuals moved slowly while making frequent changes in } \\
\text { direction and swim speed or did not move at all. Directional movements } \\
\text { consisted of holding a steady course for extended periods while } \\
\text { swimming in the upper } 2 \text { m of the water column. Fish swimming speed } \\
\text { during directional movements averaged } 0.56 \mathrm{~m} / \mathrm{s} \text { (1.3 mph) ranging from } \\
0 \text { to } 2.2 \mathrm{~m} / \mathrm{s} \text { ( } 0 \text { to } 4.9 \mathrm{mph}) \text {. Swimming speed for non-directional } \\
\text { movements averaged } 0.21 \mathrm{~m} / \mathrm{s}(0.5 \mathrm{mph}) \text {, ranging from } 0 \text { to } 1.94 \mathrm{~m} / \mathrm{s}(0 \\
\text { to } 4.3 \mathrm{mph}) \text {. }\end{array}$ & Kelly et al. (2012) \\
\hline Diet & $\begin{array}{l}\text { Dumbauld et al. examined stomachs of } 95 \text { green sturgeons commercially } \\
\text { landed in Willapa Bay, Grays Harbor, and the Columbia River estuary } \\
\text { during } 2000 \text { through } 2005 \text {. Many had empty stomachs, but fish with } \\
\text { items in their guts fed mostly on benthic prey and fish. Burrowing } \\
\text { thalassinid shrimp (mostly Neotrypaea californiensis) were important } \\
\text { food items for green sturgeons taken in Willapa Bay, Washington, during } \\
\text { summer 2003, where they represented 51\% of the biomass ingested. }\end{array}$ & Dumbauld et al. (2008) \\
\hline
\end{tabular}

Sections 4.1 through 4.7 summarize information gathered during the literature review about various aspects of green sturgeon biology. Section 4.8 assembles that information in a technical summary that addresses the specific concerns raised about the interaction between wave parks and the green sturgeon. Finally, Section 4.9 distills the technical information into a more general form that would be suitable for a broader audience.

\subsection{Green Sturgeon General Biology}

Green sturgeons are anadromous fish that spawn in freshwater about every 3 to 5 years. Adults migrate to the ocean after spawning where they disperse widely although mostly to the north from natal rivers. Spawning occurs from March through July but peaks in the period from mid-April to mid-June. 
Juveniles migrate to the ocean after spending 1 to 3 years in freshwater. The species is the most marineoriented sturgeon. Green sturgeons spawn in only the Klamath, Sacramento, and Rogue rivers, but they range from Mexico to the Bering Sea in nearshore waters. Mature males range from 139 to199 cm (55 to 78 in.) in fork length and live to be 15 to 30 years old. Mature females range from 157 to $223 \mathrm{~cm}$ (62 to $88 \mathrm{in.}$.) in fork length and live to be 17 to 40 years old. Green sturgeon begin returning to the Klamath River at about 15 to 17 years old. Green sturgeon feeding is not well known, but most probably eat benthic invertebrates and small fish.

\subsection{Status and Threats to Green Sturgeons}

In 2003, the National Marine Fisheries Service (NMFS) determined that the green sturgeon species was comprised of northern and southern distinct population segments that qualified as species under Endangered Species Act (ESA) guidance (68 FR 4433). The Northern DPS consists of populations originating from coastal watersheds northward of and including the Eel River. The Southern DPS consists of populations originating from coastal watersheds south of the Eel River and the Central Valley of California. However, the NMFS decided that neither DPS warranted listing as threatened or endangered. The NMFS added them to the Species of Concern List because of uncertainties in the structure and status of both DPSs. The National Oceanographic and Atmospheric Administration (NOAA) National Marine Fisheries Service (NMFS, or NOAA Fisheries) updated the green sturgeon status review in 2005 (NOAA Fisheries 2005) and confirmed the Northern DPS as a Species of Concern. The NMFS also proposed that the Southern DPS be listed as threatened under the ESA. The NMFS designated the Southern DPS as threatened on April 7, 2006 (71 FR 17757). In 2010, the NMFS issued protective regulations (ESA Section 4(d) rule) regarding the "take" of green sturgeons (75 FR 30714). The NMFS designated critical habitat for the green sturgeon southern DPS on October 9, 2009 (74 FR 52300). Critical habitat within marine waters includes areas within the 60-fathom [360-ft] isobath from Monterey Bay to the U.S.-Canadian border. Many coastal bays and estuaries are designated as critical habitat, including the San Francisco Estuary and Humboldt Bay in California; Coos, Winchester, Yaquina, and Nehalem bays in Oregon (Figure 4.1); Willapa Bay and Grays Harbor in Washington; and the lower Columbia River estuary from the mouth to river kilometer 74 .

The primary threat to the green sturgeon Southern DPS is the reduction of the species' natural spawning area to a limited section of the Sacramento River (NOAA 2011). Insufficient freshwater flow rates in spawning areas, contaminants (e.g., pesticides), bycatch of green sturgeon in fisheries, potential poaching (e.g., for caviar), entrainment by water projects, influence of exotic species, small population size, impassable barriers, and elevated water temperatures likely pose a threat to green sturgeons. Power generation is listed as a take activity that may occur throughout the area affected by the prohibitions for Southern DPS fish, eggs, or larvae; however, the reference is not specifically to ocean energy devices. Reviews of the possible effects of installing and operating MHK devices in coastal waters also express concern that the EMFs generated by the devices could interfere with green sturgeon migration (Nelson 2008; NMFS 2010). 


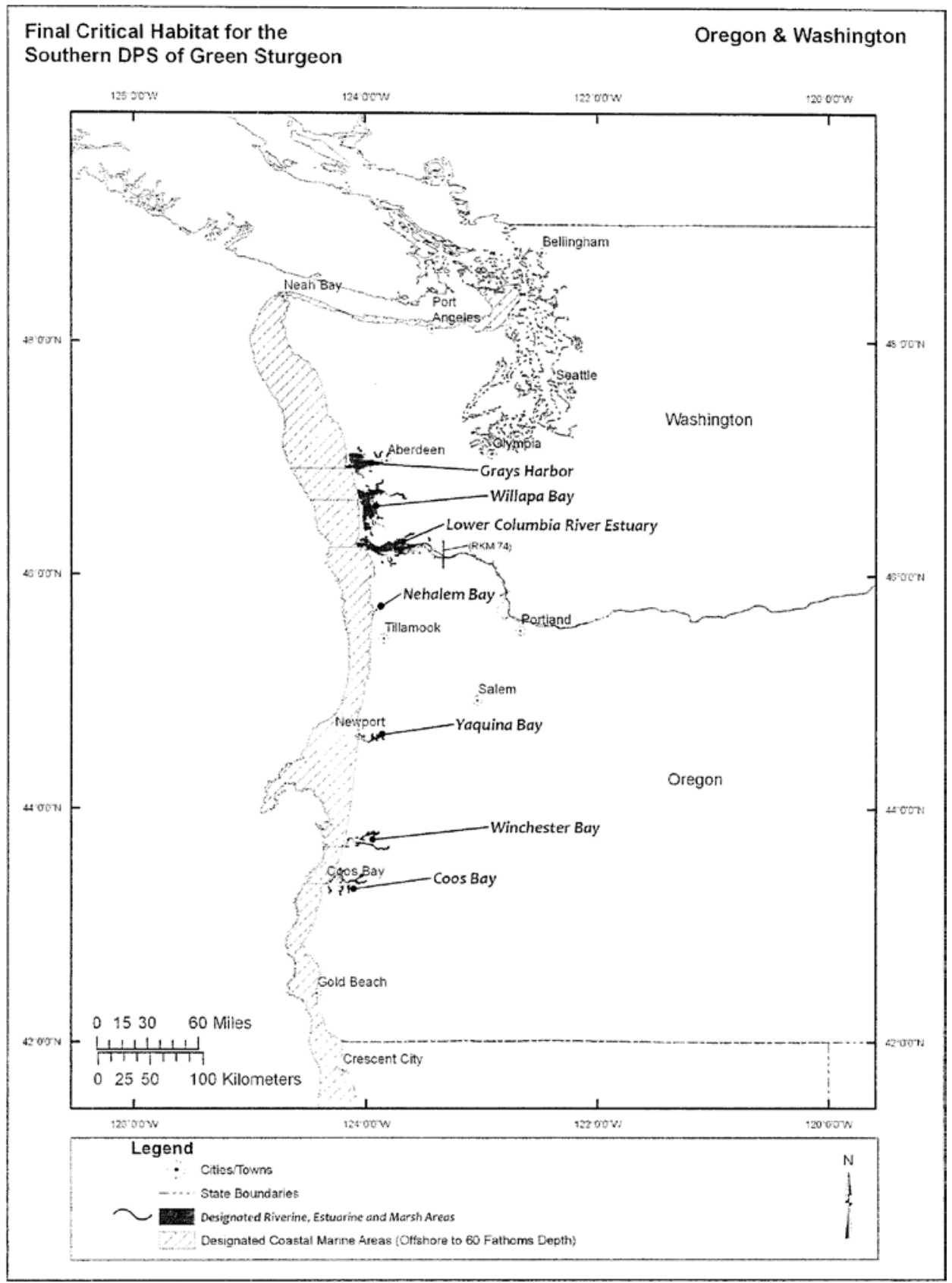

Figure 4.1. Designated critical habitat in Oregon and Washington for the green sturgeon Southern DPS (74 FR 52300).

\subsection{Green Sturgeon Marine Abundance and Habitat Use}

Huff et al. (2011) found that in waters along the Siletz Reef near Newport, Oregon (about 80 mi north of the Reedsport wave park site), green sturgeon occurred mainly at depths of 20 to $60 \mathrm{~m}$ (66 to $197 \mathrm{ft}$ ) and where water temperatures were 9.5 to $16.0^{\circ} \mathrm{C}\left(49\right.$ to $\left.61^{\circ} \mathrm{F}\right)$ but spent more time along the north-tosouth 40-m (131-ft) depth contour. Green sturgeon usually spent more time in areas with high seafloor complexity, especially where a greater proportion of the substrate consists of boulders. Erickson and Hightower (2007) found that green sturgeons tagged in the Rogue River, Oregon, left the river and 
entered the ocean within $32 \mathrm{~d}$ of tagging and migrated north. The authors estimated that the fish migrated through nearshore waters along the central Oregon coast to northwestern Vancouver Island, Canada; the distances traveled ranged from 221 to $968 \mathrm{~km}$ (137 to $601 \mathrm{mi}$ ). Erickson and Hightower (2007) identified potential concentration sites off the Oregon and Washington coasts near major coastal ports (e.g., Coos Bay to Newport, and Astoria, Oregon), major estuaries (e.g., Grays Harbor and Willapa Bay, Washington), and off northern Washington. Green sturgeon had a limited depth distribution over the continental shelf that was typically less than $100 \mathrm{~m}(<328 \mathrm{ft})$. The authors described occasional rapid vertical ascents to or near the surface, although green sturgeon typically occurred at depths of 40 to $70 \mathrm{~m}$ (131 to $230 \mathrm{ft}$ ). Green sturgeon were more active and occupied shallower depths at night than during the day.

Lindley et al. (2011) found that green sturgeon inhabit many estuarine and coastal sites over the summer, including the Columbia River estuary, Willapa Bay, Grays Harbor, and the estuaries of certain smaller rivers in Oregon, especially the Umpqua River estuary. Green sturgeons from different natal rivers exhibited different patterns of habitat use. Lindley et al. (2011) showed that fish from the Rogue and Klamath River populations frequently use the Columbia River despite earlier suggestions that the Columbia River stock consisted mostly of fish from the Sacramento River. The authors found significant variation in migratory behavior and habitat use within green sturgeon populations, some of which was related to green sturgeon size. Smaller fish make extensive use of the large estuaries in Washington in summer. Many large fish also exhibit this behavior, but some spend the summer in the Umpqua River estuary and do not use the larger estuaries. The authors suggested that green sturgeon migration patterns may be socially learned and become a spatial memory for the population. This memory could lead to continued habitat use for several generations after the habitat became suboptimal.

\subsection{Green Sturgeon Population Genetics}

Israel et al. (2004) determined that there was no genetic differentiation between the Klamath and Rogue river sturgeons or between the Columbia River and San Pablo Bay green sturgeons, but that there was a significant difference between sturgeons from the Rogue and Klamath rivers and those from San Pablo Bay and the Columbia River. Israel et al. (2009) used pairwise comparisons and genetic clustering analysis to characterize the two green sturgeon DPSs. The study showed that most individuals found in estuaries within Northern DPS boundaries originated from the threatened Southern DPS, except for those in Winchester Bay and Grays Harbor. The authors also detected few Northern DPS green sturgeon in the principal Southern DPS estuary, San Pablo Bay, California. The results support the idea that green sturgeon preferentially disperse northward, once they enter their coastal migration.

\subsection{Green Sturgeon Swimming}

Kelly et al. (2012) found that green sturgeons made non-directional and directional swimming movements in San Francisco Bay. Non-directional swimming was oriented with the bottom; individuals moved slowly while making frequent changes in direction and swim speed, or did not move at all. Swimming speed for non-directional movements averaged $0.21 \mathrm{~m} / \mathrm{s}(0.5 \mathrm{mph})$, ranging from 0 to $1.94 \mathrm{~m} / \mathrm{s}$ (0 to $4.3 \mathrm{mph}$ ). Directional swimming consisted holding of a steady course for extended periods while traveling in the upper $2 \mathrm{~m}$ of the water column. Fish swimming speed during directional movements averaged $0.56 \mathrm{~m} / \mathrm{s}(1.3 \mathrm{mph})$, ranging from 0 to $2.2 \mathrm{~m} / \mathrm{s}$ (0 to $4.9 \mathrm{mph})$. 


\subsection{Green Sturgeon Diet}

Green sturgeon feeding is not well known, but most probably eat benthic invertebrates and small fish (Adams et al. 2002). Dumbauld et al. (2008) found that many of the stomachs of 95 commercially landed green sturgeons in Willapa Bay, Grays Harbor, and the Columbia River estuary were empty. However, fish with items in their guts fed mostly on benthic prey and fish. Burrowing thalassinid shrimp (mostly Neotrypaea californiensis) were important food items for green sturgeons taken in Willapa Bay, Washington, where they represented $51 \%$ of the biomass ingested.

\subsection{Green Sturgeon and Electromagnetic Fields}

Fisher and Slater (2010) reviewed the literature on EMFs and marine animals and listed the potential sources of EMFs from wave energy conversion projects as the wave energy converter device itself, the subsea pod, and the subsea power transmission cables. EMFs consist of electric fields (E-fields) and magnetic fields (B-fields; Fisher and Slater 2010; Cada et al. 2011). E-fields can be contained within undamaged insulation surrounding the cable, but B-fields are unavoidable (Cada et al. 2011). Magnetic B-fields can produce a weak secondary electric field, referred to as an induced electric (iE) field. E- and B-field strength depends on the type and magnitude of current flowing through the cable and the construction of the cable. Both fields rapidly lose strength in seawater with increasing distance from the source, but Burying a cable would not affect the B-field magnitude, although burial keeps animals in the water column from encountering the strongest magnetic flux densities at the surface of the cable. Estimates of the B-field strength produced by various types of current-carrying cables ranged from 0 to $1.7 \mu \mathrm{T}$ at the cable and $0.61 \mu \mathrm{T}$ at about $2.5 \mathrm{~m}$ from the cable (Cada et al. 2011). By comparison, the Earth's natural magnetic flux densities range from 20 to $75 \mu \mathrm{T}$. The EMFs associated with new marine hydrokinetic energy designs have not been quantified. EMFs generated by a multi-unit array of hydrokinetic devices will differ from EMFs associated with a single unit or from the single cable sources. Estimated magnetic flux densities for cables were very high at cable surfaces, with values from 463 to $8000 \mu \mathrm{T}$; values dropped to 154 to $890 \mu \mathrm{T}$ by $0.1 \mathrm{~m}$ from the cable, then were within Earth background levels at $1 \mathrm{~m}$ from the cable.

Data on the detection of B-fields by marine species is limited. Electrosensitive species detect iEfields passively (sensing the iE-fields produced by the interaction between ocean currents with the vertical component of the Earth's magnetic field) or actively (sensing the iE-field generated by their own interaction in the water with the horizontal component of the Earth's B-field). Sturgeons are weakly electrosensitive fish that use electroreceptor senses, and others, to locate prey (Fisher and Slater 2010). However, no research has been conducted on green sturgeons. Basov (1999; full reference not available; as cited by Fisher and Slater 2010) found that sterlet sturgeon (Acipenser ruthenus) and Russian sturgeon (A. gueldenstaedtii) behavior varied in the presence of different E-field frequencies and intensities. At 1.0 to 4.0 hertz (Hz) at 0.2 to $3.0 \mu \mathrm{V} / \mathrm{cm}$, fish searched for the source and foraged actively; at $50 \mathrm{~Hz}$ at 0.2 to $0.5 \mu \mathrm{V} / \mathrm{cm}$, fish searched for the source; and at $50 \mathrm{~Hz}$ at $0.6 \mu \mathrm{V} / \mathrm{cm}$ or greater, fish avoided the source.

\subsection{Putting It All Together}

Assessing the potential effects of the proposed Reedsport wave park on the green sturgeon Southern DPS involves two basic questions-first, is it likely that green sturgeons would occur in the project area? Second, would any of the project's "byproducts” (e.g., structures, emissions) be sufficient to adversely 
affect the fish? The general review articles suggested that the primary potential effect on green sturgeon would be the interruption of migration by EMF emissions.

It is clear from the literature that although the spawning area for green sturgeon Southern DPS is within the Sacramento River and the species' "home” estuary is San Francisco Bay, once individual fish leave the river/bay, they migrate northward in nearshore waters. There is general consensus that green sturgeon use nearshore habitats where the waters are less than about $200 \mathrm{ft}$ deep, although some fish certainly use slightly deeper areas. An acoustic tracking study showed that green sturgeons occurred mainly at depths shallower than $197 \mathrm{ft}$ but spent more time along the north-to-south 131-ft depth contour (Huff et al. 2011). The study also showed that sturgeons frequently were associated with complex benthic habitats. The main structures for the Reedsport wave park would be located where water depths range from about 204 to $225 \mathrm{ft}$ (FERC 2012), so interaction between the main park structures and most migrating green sturgeons would be unlikely. The wave park would add some complexity to the seafloor in the area, but the three anchors per buoy are relatively small (Figure 2.2). Even adding 30 anchors in the 30-ac area of the park would not increase substrate complexity significantly. This lack of significant interaction between the main wave park structures and green sturgeons also reduces the likelihood that other potential issues, such as interruption of feeding and exposure to pollutants or EMFs, would adversely affect migrating green sturgeons.

The wave park would need to install a subsea cable system within the wave park and from the park to a nearshore station to transmit generated power to shore. Within the completed wave park, there would be an array of cables on the sea floor, that could accentuate the potential effects of EMF radiation on sturgeons passing through the park. The cable would be armored and the cable carrying power to shore would be buried about 3 to $6 \mathrm{ft}$ beneath the sediment surface (FERC 2012) and would extend about $2 \mathrm{mi}$ from the project area into an existing drain pipe where it would continue to shore. Green sturgeon migrating northward would have to cross this buried cable, potentially being exposed to EMF emissions. The cable armor and burial would effectively block E-field emissions (FERC 2010); however, B-field emissions would not be blocked, and sturgeons passing through the B-field would generate an iE-field. The effects of these emissions on sturgeons are unknown. Burying the cable would keep fish from encountering the strongest magnetic flux densities that occur right at the cable but that weaken with distance away from it (often within 10 to $20 \mathrm{ft}$ depending on the current intensity). The levels encountered by sturgeons would likely be within background levels for the area (Cada et al. 2011), and because most sturgeons would likely only encounter the single cable that would transmit power to shore, any behavioral effects from the exposure probably would not adversely affect the green sturgeon southern DPS population.

In summary, some Southern DPS green sturgeons migrating northward to estuaries along the Oregon and Washington coasts would encounter the wave park proposed for Reedsport, Oregon, but most sturgeons would pass by the park in shallower waters that are closer to shore. Migrating sturgeons would be exposed to some EMF levels, but those would not be expected to adversely affect the migrating green sturgeon population.

\subsection{The Reedsport, Oregon Coastal Wave Park Should Not Adversely Affect Green Sturgeons}

The green sturgeon (Acipenser medirostris; Figure 4.2) is an anadromous fish that spawns in 
freshwater about every 3 to 5 years. Adults return to the ocean after spawning, but juveniles spend 1 to 3 years in their birth river systems before they migrate to the ocean. Once in ocean waters, green sturgeons disperse widely, although they swim primarily to the north from their birth rivers. The species is the most marine-oriented sturgeon. Green sturgeons spawn only in the Klamath, Sacramento, and Rogue rivers, but they range from Mexico to the Bering Sea in nearshore ocean waters.

The National Marine Fisheries Service (NMFS) determined that the green sturgeon species was comprised of northern and southern distinct population segments (DPSs) ${ }^{1}$ that qualified as species under Endangered Species Act (ESA) guidance (68 FR 4433). The Northern DPS consists of populations originating from coastal watersheds northward of and including the Eel River. The Southern DPS consists of populations originating from coastal watersheds south of the Eel River and the Central Valley of California. The NMFS designated the Southern DPS as threatened in 2006 (71 FR 17757). The Northern DSP is listed as a Species of Concern (NOAA Fisheries 2005). The NMFS designated coastal areas from northern California to Washington from shore to the 60 -fathom (360-ft) contour as critical habitat for the Southern DPS (74 FR 52300).

Green sturgeons migrate from their birth rivers northward along the coast to reach estuaries in Oregon and Washington (Erickson and Hightower 2007). The species' status and its use of nearshore habitats during migrations raised concern that placing a wave park, such as that proposed for Reedsport, Oregon, in coastal areas along the migration route could interfere with green sturgeon migration by exposing the fish to electromagnetic fields (EMFs) that could affect fish navigation (Nelson 2008; NMFS 2010).

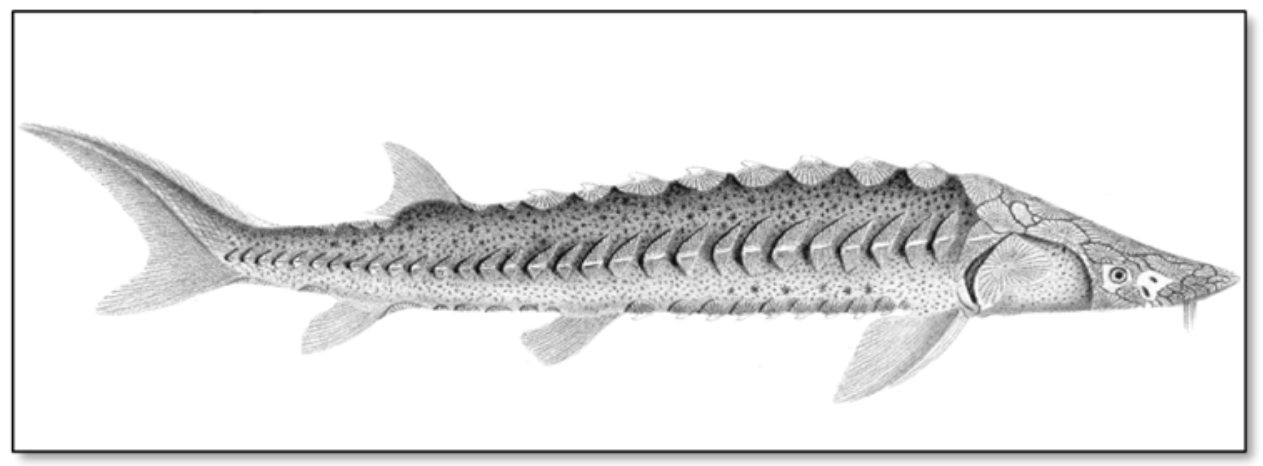

Figure 4.2. The green sturgeon (Acipenser medirostris). Source: Wikipedia. Available from http://en.wikipedia.org/wiki/Green_sturgeon (accessed September 18, 2012).

The wave park proposed for the Oregon coast would be located about $2.5 \mathrm{nmi}$ off Reedsport (FERC 2010). The park eventually would contain 10 wave buoys spaced about $330 \mathrm{ft}$ apart encompassing an area of about 30 ac. The width of the park presented to the migrating sturgeons probably would be no more than $1000 \mathrm{ft}$. Water depths at the park range from 165 to $225 \mathrm{ft}$, although most of the project structures probably would be deeper than $204 \mathrm{ft}$ (FERC 2012). Three 160-ft catenary lines would moor each power buoy to 3 of 16 anchors in the array via subsurface floats placed at a water depth of about 30 to $50 \mathrm{ft}$; 105-ft tendon lines would run from the float to the anchor on the seabed (Figure 2.2). Power generated by the buoy array would be carried from the cable network within the wave park to shore via an

\footnotetext{
${ }^{1}$ A DPS is the smallest division of a taxonomic species that is permitted to be protected under the ESA. A DPS must be distinct from and significant to the rest of the species to which it belongs. A DPS must be able to be assigned a conservation status according to the ESA.s standards for listing.
} 
armored subsea transmission cable, buried in the seabed to a depth of 3 to $6 \mathrm{ft}$ (FERC 2012). The cable would extend from the underwater substation pod to the outlet of an existing wastewater discharge pipeline about $0.5 \mathrm{mi}$ from shore. The subsea cable would enter the discharge pipeline and extend through the pipeline passing under the nearshore area, beach, and dunes. Probably the most important direct effects of an MHK wave park on sturgeons are the collisions with underwater structures, habitat alteration, and potential interruption of migration pathways by exposure to electromagnetic fields (EMFs).

To evaluate these risks, a first step is to identify the typical habitat used by migrating green sturgeons. Although they can occur at water depths as deep as about $328 \mathrm{ft}$ (Erickson and Hightower 2007), sturgeons typically stay in waters that are less than about $200 \mathrm{ft}$ deep; most occur at about the 131-ft depth contour (Huff et al. 2011). Therefore, most migrating sturgeons probably would not encounter the wave park directly and would not be exposed to the risks posed by it. Some migrating sturgeons may encounter the wave park directly and be exposed to the risks of doing so.

Sturgeons encountering the park risk injury from collisions with the park's underwater structures. However, this risk is likely very low because the structures are small and the anchors are similar to rocky outcrops that the sturgeons routinely encounter while swimming along the coast (Huff et al. 2011).

The wave park could alter benthic habitats by placing hard structures on a primarily sand seafloor. Some habitat no doubt would change from soft bottom to hard bottom. However, the structural elements placed on the seafloor would occupy a very the small footprint (about 2\%) within the wave park that would occupy the site (FERC 2010). Thus the potential habitat change would be negligible, and the potential effects on green sturgeons would not be important.

The main concern is that wave parks would expose green sturgeons to EMFs that could interfere with the species' migration patterns. As mentioned previously, most sturgeons would not directly encounter the wave park and would not be exposed to EMFs in the park. Sturgeons swimming along the coast would encounter a subsea network of cables if they swam through the wave park or would have to cross the undersea cable that would carry generated power from the park to shore and would be exposed to EMFs from the cable. The metal shielding covering the cables would reduce or eliminate E-field emissions from the cables (Gill et al. 2012). However, some magnetic-field (B-field) and and resulting induced electric field (iE-field) radiation would be emitted by the underwater structures and the power transmission cables. The B and iE field emissions should decrease rapidly with distance from the cable (Cada et al. 2011), which would reduce the degree of exposure to the migrating sturgeons. Although the specific effects of EMF emissions on sturgeon behavior and their potential implications are not well known, the reduction of EMF strength within a short distance from the cable and that most sturgeons use areas that are inshore form the porposed wave park, suggest that the emisisons probably would not have an overall adverse effect on the migrating green sturgeon southern DPS population.

Evidence gathered to date and presented above indicates that the proposed wave parks should not adversely affect migrating green sturgeon southern DPS population by increasing the risk of injury from collisions with underwater structures, changing seafloor habitat, or exposing the sturgeons to EMFs. 



\subsection{References}

68 FR 4433. January 29, 2003. "Endangered and Threatened Wildlife and Plants; 12-Month Finding on a Petition to List North American Green Sturgeon as a Threatened or Endangered Species.” Federal Register. U.S. Department of Commerce.

69 FR 19975. April 15, 2004. "Endangered and Threatened Species; Take of Anadromous Fish.” Federal Register. U.S. Department of Commerce.

71 FR 17757. April 7, 2006. "Endangered and Threatened Wildlife and Plants: Threatened Status for Southern Distinct Population Segment of North American Green Sturgeon. Final rule.” Federal Register. U.S. Department of Commerce.

74 FR 52300. October 9, 2009. “Endangered and Threatened Wildlife and Plants: Final Rulemaking To Designate Critical Habitat for the Threatened Southern Distinct Population Segment of North American Green Sturgeon. Final Rule.” Federal Register. U.S. Department of Commerce.

75 FR 30714. June 2, 2010. “Endangered and Threatened Wildlife and Plants: Final Rulemaking To Establish Take Prohibitions for the Threatened Southern Distinct Population Segment of North American Green Sturgeon.” Federal Register. U.S. Department of Commerce.

76 FR 61599. October 5, 2011. "Endangered and Threatened Wildlife and Plants; Revised Critical Habitat for the Marbled Murrelet.” Federal Register. U.S. Department of Interior.

Adams PB, C Grimes, JE Hightower, ST Lindley, and ML Moser. 2002. Status Review for North American Green Sturgeon, Acipenser medirostris. Southwest Fisheries Science Center, National Marine Fisheries Service, National Oceanic and Atmospheric Administration, Santa Cruz, California.

Adams PB, C Grimes, JE Hightower, ST Lindley, ML Moser, and MJ Parsley. 2007. "Population Status of North American Green Sturgeon, Acipenser medirostris.” Environmental Biology of Fishes 79(3-4):339-356.

Basov BM. 1999. "Behavior of sterlet sturgeon (Acipenser ruthenus) and Russian sturgeon (A. gueldenstaedtii) in low-frequency electric fields.” Journal of Ichthyology 39:782-787

Becker BH and SR Beissinger. 2006. "Centennial decline in the trophic level of an endangered seabird after fisheries decline.” Conservation Biology 20(2):470-479.

Becker BH, MZ Peery, and SR Beissinger. 2007. “Ocean climate and prey availability affect the trophic level and reproductive success of the marbled murrelet, an endangered seabird." Marine EcologyProgress Series 329:267-279.

Benson RL, S Turo, and BW McCovey. 2007. "Migration and movement patterns of green sturgeon (Acipenser medirostris) in the Klamath and Trinity Rivers, California, USA.” Environmental Biology of Fishes 79(3-4):269-279. 
Boehlert GW and AB Gill. 2010. "Environmental and Ecological Effects of Ocean Renewable Energy Development a Current Synthesis.” Oceanography 23:68-81.

Boehlert GW, GR McMurray, and CE Tortorici (eds). 2008. Ecological Effects of Wave Energy Development in the Pacific Northwest: A Scientific Workshop, October 11-12, 2007. NOAA Technical Memorandum NMFS-F/SPO-92, Northwest Fisheries Science Center, National Marine Fisheries Service, National Oceanic and Atmospheric Administration, Seattle, Washington. Available at http://spo.nmfs.noaa.gov/tm/ (October 2010).

Burger AE. 2002. Conservation Assessment of Marbled Murrelets in British Columbia: A Review of the Biology, Populations, Habitat Associations, and Conservation. Technical Report Series No. 387, Canadian Wildlife Service, Pacific and Yukon Region, British Columbia. Issued under the Authority of the Minister of Environment Canadian Wildlife Service.

Burger AE and TA Chatwin. 2002. Multi-Scale Studies of Populations, Distribution and Habitat Associations of Marbled Murrelets in Clayoquot Sound, British Columbia. Ministry of Water, Land and Air Protection, Victoria, British Columbia.

Burger AE, CL Hitchcock, EA Stewart, and GK Davoren. 2008. “Coexistence and spatial distributions of marbled murrelets (Brachyramphus marmoratus) and other alcids off southwest Vancouver Island, British Columbia.” Auk 125(1):192-204.

Cada GF, MS Bevelhimer, KP Riemer, JW Turner. 2011. Effects on Freshwater Organisms of Magnetic Fields Associated with Hydrokinetic Turbines. ORNL/TM-2011/244, Oak Ridge National Laboratory, Oak Ridge, Tennessee.

Cooper BA, MG Raphael, and MZ Peery. 2006. “Trends in radar-based counts of marbled murrelets on the Olympic Peninsula, Washington, 1996-2004.” The Condor 108(4):936-947.

Day RH, AK Prichard, and DA Nigro. 2003. "Ecological specialization and overlap of Brachyramphus murrelets in Prince William Sound, Alaska.” Auk 120(3):680-699.

Dumbauld BR, DL Holden, and OP Langness. 2008. "Do sturgeon limit burrowing shrimp populations in Pacific Northwest Estuaries?” Environmental Biology of Fishes 83(3):283-296.

Elliott KH, M Hewett, GW Kaiser, and RW Blake. 2004. "Flight energetics of the marbled murrelet, Brachyramphus marmoratus.” Canadian Journal of Zoology-Revue Canadienne De Zoologie 82(4):644652.

Erickson DL. and JE Hightower. 2007. “Oceanic distribution and behavior of green sturgeon.” American Fisheries Society Symposium 56:197-211.

Erickson DL and MAH Webb. 2007. "Spawning periodicity, spawning migration, and size at maturity of green sturgeon, Acipenser medirostris, in the Rogue River, Oregon.” Environmental Biology of Fishes 79(3-4):255-268.

Falxa G, J Baldwin, D Lynch, SL Miller, SK Nelson, SF Pearson, MG Raphael, C Strong, T Bloxton, B Galleher, B Hogoboom, M Lance, and R Young. 2011. Marbled Murrelet Effectiveness Monitoring, 
Northwest Forest Plan: 2009 And 2010 Summary Report. Northwest Forest Plan Interagency Regional Monitoring Program. Available from http://www.reo.gov/monitoring/reports/murrelet/MAMU_20092010_EM_Annual\%20Monitoring\%20Report.pdf (September 2012).

FERC - Federal Energy Regulatory Commission. 2010. Environmental Assessment for Hydropower License: Reedsport OPT Wave Park Project FERC Project No. 12713-002; Oregon. Federal Energy Regulatory Commission, Office of Energy Projects, Division of Hydropower Licensing, Washington, D.C.

FERC - Federal Energy Regulatory Commission. 2012. Reedsport OPT Wave Park, LLC, Project No. 12713-002, Order Issuing Original License (August 13, 2012). Federal Energy Regulatory Commission, Office of Energy Projects, Division of Hydropower Licensing, Washington, D.C.

Fisher C and Slater. 2010. Effects of Electromagnetic Fields on Marine Species: A Literature Review. Prepared for the Oregon Wave Energy Trust.

Gill AB, M Bartlett, and F Thomsen. 2012. "Potential interactions between diadromous fishes of U.K. conservation importance and the electromagnetic fields and subsea noise from marine renewable energy developments.” Journal of Fish Biology 81:664-695.

Grecian WJ, R Inger, MJ Attrill, S Bearhop, BJ Godley, MJ Witt, and SC Votier. 2010. "Potential Impacts of Wave-Powered Marine Renewable Energy Installations on Marine Birds.” Ibis 152:683-697.

Hamer TE, DE Varland, TL McDonald, and D Meekins, 2008. "Predictive model of habitat suitability for the marbled murrelet in western Washington.” Journal of Wildlife Management 72(4):983-993.

Haynes TB, SK Nelson, and SH Newman. 2010. "Diel shifts in the marine distribution of marbled murrelets near Port Snettisham, southeast Alaska.” Waterbirds 33(4):471-478.

Haynes TB, SK Nelson, F Poulsen, and VM Padula. 2011. "Spatial distribution and habitat use of marbled murrelets Brachyramphus marmoratus at sea in Port Snettisham, Alaska.” Marine Ornithology 39:151-162.

Haynes TB and CLK Robinson. 2011. "Re-use of shallow sediment patches by Pacific sand lance (Ammodytes hexapterus) in Barkley Sound, British Columbia, Canada.” Environmental Biology of Fishes 92(1):1-12.

Hébert PN and RT Golightly. 2008. "At-sea distribution and movements of nesting and non-nesting marbled murrelets Brachyramphus marmoratus in northern California.” Marine Ornithology 36: 99-105.

Hébert PN, RT Golightly, and HR Carter. 2012. “Aspects of Marbled Murrelet Biology from Laying to Hatching.” Pacific Seabird Group, 39th Annual Meeting, Turtle Bay, Hawaii, February 7-10, 2012. \{Abstract].

Huff DD, ST Lindley, PS Rankin, and EA Mora. 2011. "Green sturgeon physical habitat use in the coastal Pacific Ocean.” Plos One 6(9). 
Israel JA, KJ Bando, EC Anderson, and B May. 2009. "Polyploid microsatellite data reveal stock complexity among estuarine North American green sturgeon (Acipenser medirostris).” Canadian Journal of Fisheries and Aquatic Sciences 66:1491-1504.

Israel JA, JF Cordes, MA Blumberg, and B May. 2004. “Geographic patterns of genetic differentiation among collections of green sturgeon.” North American Journal of Fisheries Management 24(3):922-931.

Israel JA and B May. 2010. "Indirect genetic estimates of breeding population size in the polyploid green sturgeon (Acipenser medirostris).” Molecular Ecology 19(5):1058-1070.

Janssen MH, P Arcese, TK Kyser, DF Bertram, L McFarlane Tranquilla, TD Williams, and DR Norris. 2009. "Pre-breeding diet, condition and timing of breeding in a threatened seabird, the marbled murrelet Brachyramphus marmoratus.” Marine Ornithology 37:33-40.

Jodice PGR and MW Collopy. 1999. "Diving and foraging patterns of marbled murrelets (Brachyramphus marmoratus): testing predictions from optimal-breathing models.” Canadian Journal of Zoology 77: 1409-1418.

Johnson SW, JF Thedinga, and KM Munk. 2008. "Distribution and use of shallow-water habitats by Pacific sand lances in southeastern Alaska.” Transactions of the American Fisheries Society 137(5):1455-1463.

Kelly JT and AP Klimley. 2012. "Relating the swimming movements of green sturgeon to the movement of water currents.” Environmental Biology of Fishes 93(2):151-167.

Kropp RK. 2010. Review of Recent Literature Relevant to the Environmental Effects of Marine and Hydrokinetic Energy Devices. Task 2.1.3: Effects on Aquatic Organisms - Fiscal Year 2010 Progress Report. PNNL-19903, Pacific Northwest National Laboratory, Richland, Washington.

Langton R, IM Davies, and BE Scott. 2011. "Seabird Conservation and Tidal Stream and Wave Power Generation: Information Needs for Predicting and Managing Potential Impacts.” Marine Policy 35:623-630.

Lindley ST, DL Erickson, ML Moser, G Williams, OP Langness, BW McCovey, M Belchik, D Vogel, W Pinnix, JT Kelly, JC Heublein, and AP Klimley. 2011. "Electronic tagging of green sturgeon reveals population structure and movement among estuaries." Transactions of the American Fisheries Society 140(1):108-122.

Lindley ST, ML Moser, DL Erickson, M Belchik, DW Welch, EL Rechisky, JT Kelly, J Heublein, and AP Klimley. 2008. "Marine migration of North American green sturgeon." Transactions of the American Fisheries Society 137(1):182-194.

Malt JM and DB Lank. 2009. "Marbled Murrelet nest predation risk in managed forest landscapes: Dynamic fragmentation effects at multiple scales.” Ecological Applications 19(5):1274-1287.

Meyer CB and SL Miller. 2002. "Use of fragmented landscapes by marbled murrelets for nesting in southern Oregon.” Conservation Biology 16(3):755-766. 
Miller SL, CB Meyer, and CJ Ralph. 2002. "Land and seascape patterns associated with marbled murrelet abundance offshore.” Waterbirds 25(1):100-108.

Miller, SL; CJ Ralph, MG Raphael, C Strong, CW Thompson, J Baldwin, MH Huff, GA Falxa. 2006. "At-Sea Monitoring of Marbled Murrelet Population Status and Trend in the Northwest Forest Plan Area.” In Huff MH, MG Raphael, SL Miller, SK Nelson, and J Baldwin, technical coordinators. Northwest Forest Plan-The First 10 Years (1994-2003): Status And Trends Of Populations And Nesting Habitat For The Marbled Murrelet, General Technical Report PNW-GTR-650, Chapter 3. U.S. Department of Agriculture, Forest Service, Pacific Northwest Research Station, Portland, Oregon.

National Marine Fisheries Service (NMFS). 2010. Federal Recovery Outline North American Green Sturgeon Southern Distinct Population Segment. National Marine Fisheries Service, Southwest Region, Santa Rosa, California.

National Marine Fisheries Service (NMFS). 2011. Green Sturgeon (Acipenser medirostris). Accessed March 9, 2011 at http://www.nmfs.noaa.gov/pr/species/fish/greensturgeon.htm.

Nelson K, MG Raphael, and P. Harrison. 2009. Independent Science Panel Review of Potential Impacts to Marbled Murrelets Relating to the Radar Ridge Wind Resource Area. Report prepared for Peter Goldmark, Washington State Commissioner of Public Lands.

Nelson, PA. 2008. "Ecological Effects of Wave Energy Conversion Technology on California's Marine and Anadromous Fishes.” In Developing Wave Energy in Coastal California: Potential Socio-Economic and Environmental Effects, PA Nelson, D Behrens, J Castle, G Crawford, RN Gaddam, SC Hackett, J Largier, DP Lohse, KL Mills, PT Raimondi, M Robart, WJ Sydeman, SA Thompson, and S Woo, CEC-500-2008-083, pp. 111-135. California Energy Commission, PIER Energy-Related Environmental Research Program \& California Ocean Protection Council, Sacramento, California.

Nelson SK, MH Huff, SL Miller, and MG Raphael. 2006. “Marbled Murrelet Biology: Habitat Relations and Populations.” In Huff MH, MG Raphael, SL Miller, SK Nelson, and J Baldwin, technical coordinators. Northwest Forest Plan-The First 10 Years (1994-2003): Status And Trends Of Populations And Nesting Habitat For The Marbled Murrelet, General Technical Report PNW-GTR-650, Chapter 2. U.S. Department of Agriculture, Forest Service, Pacific Northwest Research Station, Portland, Oregon.

NOAA Fisheries. 2005. Green Sturgeon (Acipenser medirostris) Status Review Update. Southwest Fisheries Science Center, NOAA Fisheries, Santa Cruz, California.

Norris DR, P Arcese, D Preikshot, DF Bertram, and TK Kyser. 2007. "Diet reconstruction and historic population dynamics in a threatened seabird.” Journal of Applied Ecology 44(4):875-884.

Peery MZ and RW Henry. 2010. "Recovering marbled murrelets via corvid management: A population viability analysis approach.” Biological Conservation 143(11):2414-2424.

Peery MZ, SH Newman, CD Storlazzi, and SR Beissinger. 2009. "Meeting reproductive demands in a dynamic upwelling system: Foraging strategies of a pursuit-diving seabird, the marbled murrelet.” Condor 111(1):120-134. 
Piatt JF, KJ Kuletz, AE Burger, SA Hatch, VL Friesen, TP Birt, ML Arimitsu, GS Drew, AMA Harding, and KS Bixler. 2007. Status Review of the Marbled Murrelet (Brachyramphus marmoratus) in Alaska and British Columbia. U.S. Geological Survey Open-File Report 2006-1387, available from http://pubs.usgs.gov/of/2006/1387/ (September 2012).

Robards MD and JF Piatt. 1999. "Biology of the genus Ammodytes, the sand lances.” USDA Forest Service Pacific Northwest Research Station Research Paper 521:1-16.

Ronconi RA and AE Burger. 2008. "Limited foraging flexibility:increased foraging effort by a marine predator does not buffer against scarce prey.” Marine Ecology-Progress Series 366:245-258.

Speckman SG, JF Piatt, and AM Springer. 2003. "Deciphering the social structure of marbled murrelets from behavioral observations at sea.” Waterbirds 26(3):266-274.

Strong CS. 2005. Marine Birds of the Near Shore Waters of Clatsop Spit: An Assessment of Composition, Abundance, and Potential Effects from Dredge Spoil Deposition Adjacent to the South Jetty of the Columbia River. Prepared for Institute for Natural Resources, Oregon State University, Corvallis, Oregon.

Stumpf JP, N Denis, TE Hamer, G Johnson, and J Verschuyl. 2011. "Flight height distribution and collision risk of the marbled murrelet Brachyramphus marmoratus: methodology and preliminary results.” Marine Ornithology 39:123-128.

Thompson SA, J Castle, KL Mills, and WJ Sydeman. 2008. "Wave Energy Conversion Technology Development in Coastal California: Potential Impacts on Marine Birds and Mammals.” In Developing Wave Energy in Coastal California: Potential Socio-Economic and Environmental Effects, PA Nelson, D Behrens, J Castle, G Crawford, RN Gaddam, SC Hackett, J Largier, DP Lohse, KL Mills, PT Raimondi, M Robart, WJ Sydeman, SA Thompson, and S Woo, CEC-500-2008-083, pp. 137-163. California Energy Commission, PIER Energy-Related Environmental Research Program \& California Ocean Protection Council, Sacramento, California.

US Army Corps of Engineers (USACE). 2004. Cape Wind energy draft environmental impact statement. Draft EIS/EIR/DRI. File no. NAE-2004-338-1. Available

at: http://www.nae.usace.army.mil/projects/ma/ccwf/deis.htm. Accessed June 26, 2010. U.S. Army Corps of Engineers.

US Fish and Wildlife Service (USFWS). 1997. Recovery Plan for the Threatened Marbled Murrelet (Brachyramphus marmoratus) in Washington, Oregon, and California. U.S. Fish and Wildlife Service, Region 1, Portland, Oregon.

US Fish and Wildlife Service (USFWS). 2009. Marbled Murrelet (Brachyramphus marmoratus) 5-Year Review. U.S. Fish and Wildlife Service, Washington Fish and Wildlife Office, Lacey, Washington.

US Fish and Wildlife Service (USFWS). 2012. Report on Marbled Murrelet Recovery Implementation Team Meeting and Stakeholder Workshop. U.S. Fish and Wildlife Service, Washington Fish and Wildlife Office, Lacey, Washington. 
Watanabe YY, K Sato, Y Watanuki, A Takahashi, Y Mitani, M Amano, K Aoki, T Narazaki, T Iwata, S Minamikawa, and N Miyazaki. 2011. "Scaling of swim speed in breath-hold divers." Journal of Animal Ecology 80:57-68.

Watanuki Y, Y Niizuma, GW Gabrielsen, K Sato, and Y Naito. 2003. "Stroke and glide of wingpropelled divers: deep diving seabirds adjust surge frequency to buoyancy change with depth.” Proceedings of the Royal Society of London Series B-Biological Sciences 270:483-488.

Watanuki Y, S Wanless, M Harris, JR Lovvorn, M Miyazaki, H Tanaka, and K Sato. 2006. “Swim speeds and stroke patterns in wing-propelled divers: a comparison among alcids and a penguin.” Journal of Experimental Biology. 209:1217-1230.

Wong SNP, RA Ronconi, AE Burger, and B Hansen. 2008. "Marine distribution and behavior of juvenile and adult marbled murrelets off southwest Vancouver Island, British Columbia: Applications for monitoring.” Condor 110(2):306-315.

Yen PPW, F Huettmann, and F Cooke. 2004. "A large-scale model for the at-sea distribution and abundance of Marbled Murrelets (Brachyramphus marmoratus) during the breeding season in coastal British Columbia, Canada.” Ecological Modelling 171(4):395-413. 


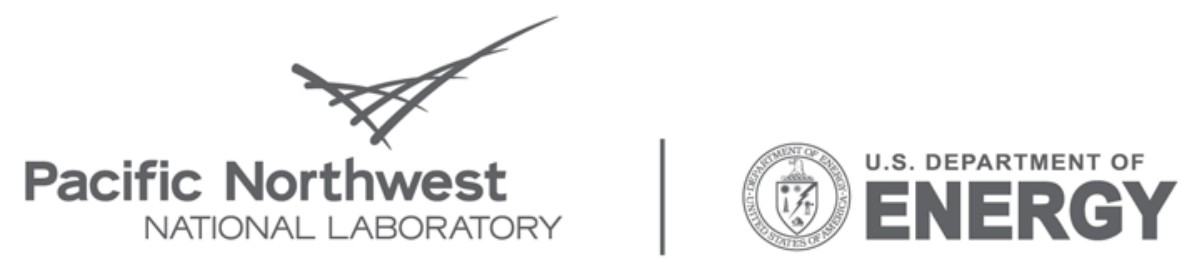

Proudly Operated by Battelle Since 1965

902 Battelle Boulevard

P.O. Box 999

Richland, WA 99352

1-888-375-PNNL (7665)

www.pnl.gov 